\title{
CLINICAL FEATURES AND COURSE OF ANKYLOSING SPONDYLITIS
}

\author{
As SEen in a Follow-up of 222 Hospital Referred Cases
}

BY

\author{
M. WILKINSON AND E. G. L. BYWATERS \\ From the Department of Medicine, Postgraduate Medical School of London
}

Despite the increasing recognition of ankylosing spondylitis, particularly as a result of two world wars, there is little information relating to the course of this disease on which to base prognosis. While there are many studies dealing with the clinical manifestations, to date only Blumberg and Ragan (1956) have attempted to study the physical condition and functional ability of patients many years after the onset of ankylosing spondylitis, and even here the value of the study was diminished because of inability to trace approximately half the patients. The present study details a more complete follow-up of a group of spondylitics seen and treated at one hospital over 16 years. Although primarily concerned with the follow-up results, various aspects of the clinical picture have been studied and where these are of interest they will be presented.

\section{Patients Studied}

During the period January, 1940, to December, 1955, 242 patients were diagnosed at the Hammersmith Hospital as suffering from ankylosing spondylitis. Approximately two-thirds of these patients had been referred to the radiotherapy department from outlying hospitals and most of the others had attended the outpatient clinic for rheumatic diseases.

While no claim can be made for a hospital-referred group to represent the true spondylitic population, the latter has never been defined, and the hospital-referred group remains the one about which it is desirable to know the outcome, whether the disease be treated or untreated. Since early cases demand radiography for diagnosis, the hospital-referred group corresponds perhaps nore closely than in other categories of disease to the diagnosable entity, apart from special population surveys.

During 1955 and 1956 an attempt was made to trace all these patients and, wherever possible, they were interviewed and examined. Where personal examinations were not possible, reports were obtained on the patients' physical state following attendances at other hospitals, and in a few cases patients were asked to complete a questionnaire.

Of the original 242 patients, twenty were excluded from further study, seven because of inadequate initial information or radiographs, seven because of incorrect diagnoses, and six because there were only minimal or doubtful changes in the sacro-iliac joint $x$ rays and no physical signs to support a diagnosis of ankylosing spondylitis. Follow-up details of the remaining 222 patients are shown in Table I. Only ten of these patients could not be traced, and seventeen had died during the follow-up period.

TABLE I

FOLLOW-UP DETAILS OF 222 PATIENTS WITH ANKYLOSING SPONDYLITIS

\begin{tabular}{|c|c|c|c|}
\hline \multirow{2}{*}{ No. of Patients } & \multicolumn{2}{|c|}{ Sex } & \multirow{2}{*}{ Type of Follow-up } \\
\hline & Male & Female & \\
\hline $\begin{array}{r}17 \\
142 \\
33\end{array}$ & $\begin{array}{r}16 \\
122 \\
26\end{array}$ & $\begin{array}{r}1 \\
20 \\
7\end{array}$ & $\begin{array}{l}\text { Known to be dead } \\
\text { Seen personally at follow-up } \\
\text { Follow-up by proxy at an- } \\
\text { other hospital }\end{array}$ \\
\hline $\begin{array}{l}20 \\
10\end{array}$ & $\begin{array}{l}9 \\
8\end{array}$ & $\begin{array}{r}11 \\
2\end{array}$ & $\begin{array}{l}\text { Postal follow-up } \\
\text { Follow-up unsuccessful }\end{array}$ \\
\hline 222 & 181 & 41 & Totals \\
\hline
\end{tabular}

All 222 patients fulfilled the following criteria:

(1) All had a clinical picture compatible with the diagnosis of ankylosing spondylitis, the minimal requirement being backache.

(2) All showed radiological changes in both sacroiliac joints. In a few cases only $x$-ray reports were available, but in these appropriate changes in the sacro-iliac joints were described and the patients themselves showed advanced changes of ankylosing spondylitis.

Most of the patients had received a variety of treatments including radiotherapy. We have made no detailed attempt to relate treatment to course since there is no evidence showing significant beneficial effects over a prolonged period of any particular type of treatment. We have been concerned with the long-term course and state of a patient with this disease treated 
by the methods usually advocated over the last 16 years in Great Britain.

Apart from the information obtained at follow-up visits, most of these patients had been seen intermittently at Hammersmith Hospital over periods varying from 1 to 20 years (mean follow-up 4.6 years), and considerable information was available from the case records.

Analysis of the cases when first seen (Table II) showed that the type of case referred to hospital during the period studied did not vary significantly, except in one respect. Those patients seen during the years 1951 to 1955 showed a significantly better functional status when first seen than did the earlier patients. The large increase in the number of cases seen during 1951 to 1955 was due to the closing down of a nearby radiotherapy centre and consequent transfer of its patients in 1950.

TABLE II

CLINICAL FEATURES

\begin{tabular}{|c|c|c|c|c|c|}
\hline \multirow{2}{*}{\multicolumn{2}{|c|}{$\begin{array}{l}\text { Clinical Features of } \\
\text { When First Seen }\end{array}$}} & & & Year & \\
\hline & & . . . & $1940-45$ & $1946-50$ & $1951-55$ \\
\hline \multicolumn{2}{|c|}{ Total Patients Seen } & . & 28 & 61 & 133 \\
\hline \multicolumn{2}{|c|}{ Percentage of Females } & . & 11 & 20 & 20 \\
\hline \multicolumn{2}{|c|}{ Average Age (yrs) } & - & $35 \cdot 0$ & $38 \cdot 9$ & $38 \cdot 2$ \\
\hline \multirow{2}{*}{$\begin{array}{l}\text { Percentage } \\
\text { Onset }\end{array}$} & \multirow{2}{*}{ Type of } & Spinal & 67 & 82 & 82 \\
\hline & & Extraspinal $\ldots$ & 33 & 18 & 18 \\
\hline \multirow{3}{*}{$\begin{array}{l}\text { Percentage } \\
\text { of Disease }\end{array}$} & \multirow{3}{*}{$\begin{array}{l}\text { Duration } \\
\text { (yrs) }\end{array}$} & $0-5 \quad \ldots$ & 41 & 41 & 36 \\
\hline & & $6-10$ & 33 & 28 & 30 \\
\hline & & Over 10 & 26 & 31 & 34 \\
\hline \multicolumn{3}{|c|}{ Previous Radiotherapy (per cent.) } & 11 & 16 & 18 \\
\hline \multicolumn{3}{|c|}{ Working (Grade 5 and 4 ) } & 57 & 56 & $74^{*}$ \\
\hline \multirow{3}{*}{$\begin{array}{l}\text { Percentage } \\
\text { Function- } \\
\text { al State }\end{array}$} & \multicolumn{2}{|c|}{$\begin{array}{l}\text { Unable to Work but } \\
\text { Mobile (Grade 3) }\end{array}$} & 11 & 18 & 13 \\
\hline & \multicolumn{2}{|c|}{$\begin{array}{l}\text { Chairbound or Bedridden } \\
\text { (Grade } 2 \text { and } 1)\end{array}$} & 32 & 26 & 13 \\
\hline & \multicolumn{2}{|c|}{ Mean Functional Grade } & $3 \cdot 4$ & $3 \cdot 4$ & $3 \cdot 9$ \\
\hline
\end{tabular}

* Difference significant at 5 per cent. level.

Significance has been assessed by the use of the $\chi^{2}$ test, using Yates' modification where appropriate.

\section{Clinical Features at Onset}

Sex Incidence and Age at Onset.-Table III shows the sex ratio and distribution of ages at which initial symptoms were noted. The sex ratio for the whole series was 4.4 males to 1 female. Because of the occasional history of episodes of peripheral arthritis or arthralgia often diagnosed as rheumatic fever, such an episode was accepted as marking the onset of the spondylitis only when there were permanent residua or when the peripheral joint symptoms merged into the spinal symptoms.
TABLE III

SEX INCIDENCE AND AGE AT WHICH INITIAL SYMPTOMS WERE NOTICED IN 222 PATIENTS WITH ANKYLOSING SPONDYLITIS

\begin{tabular}{|c|c|c|c|c|c|c|}
\hline \multirow{2}{*}{$\begin{array}{c}\text { Age at } \\
\text { Onset } \\
\text { (yrs) }\end{array}$} & & \multirow{2}{*}{$\begin{array}{c}\text { No. } \\
\text { of } \\
\text { Patients }\end{array}$} & \multicolumn{2}{|c|}{ Sex } & \multicolumn{2}{|c|}{$\begin{array}{l}\text { Percentage Total } \\
\text { Cases in each } \\
\text { Decade }\end{array}$} \\
\hline & & & Male & Female & Male & Female \\
\hline $10-19 \ldots$ & . & 40 & 30 & 10 & $16 \cdot 6$ & $24 \cdot 4$ \\
\hline $20-29 \ldots$ & $\ldots$ & 101 & 87 & 14 & $48 \cdot 1$ & $34 \cdot 1$ \\
\hline $30-39 \ldots$ & . & 56 & 48 & 8 & $26 \cdot 5$ & $19 \cdot 5$ \\
\hline $40-49$ & . & 20 & 13 & 7 & \multirow{2}{*}{$8 \cdot 8$} & \multirow{2}{*}{$22 \cdot 0$} \\
\hline 50 and Over & . & 5 & 3 & 2 & & \\
\hline Total & . . & 222 & 181 & 41 & 100 & 100 \\
\hline
\end{tabular}

70 per cent. of the patients had first noticed symptoms between the ages of 20 and 40 years and, though five patients remembered no disability before the sixth decade, physical and radiological evidence 8 at the time of the first examination suggested that the disease had in fact begun before the age of 50 years. While the initial symptoms in males occurred mainly in the third and fourth decades, the onset in females was spread more evenly over five decades, the difference being significant at the 5 per cent. level.

The earliest age at onset was 11 years (Case 1):

Case 1, a male accountant aged 36 in 1955, had fir noticed jabbing pains in both buttocks radiating dox to the mid-thighs at the age of 11 ; the pains occurred int bouts lasting several months, but did not incapacitate him and at the age of 21 he joined the Royal Air Force. The work was mainly clerical but 3 years later, 13 years after the initial symptoms, he was discharged with a $\overrightarrow{\vec{P}}$ diagnosis of ankylosing spondylitis. Radiotherapy to the lower spine relieved all pain but had to be repeated for an exacerbation in the cervical spine 3 years later. At the age of 33 years bilateral pulmonary tuberculosis was diagnosed. When last seen in 1955 the patient had a rigid spine and a normal sedimentation rate.

Heredity.-Table IV shows the frequency of $\frac{0}{3}$ rheumatic complaints in the families of these

$$
\text { TABLE IV }
$$

FAMILY HISTORY OF 222 PATIENTS WITH ANKYLOSING SPONDYLITIS

\begin{tabular}{|c|c|c|c|c|}
\hline \multirow{2}{*}{ Relatives' Status } & \multirow{2}{*}{$\begin{array}{c}\text { No. } \\
\text { of } \\
\text { Patients }\end{array}$} & \multicolumn{2}{|c|}{ Sex } & \multirow{2}{*}{$\begin{array}{l}\text { No. of } \\
\text { Relatives } \\
\text { Affected }\end{array}$} \\
\hline & & Male & Female & \\
\hline $\begin{array}{l}\text { Hospital Diagnosis of } \\
\text { Ankylosing Spondylitis .. }\end{array}$ & 14 & 10 & 4 & 17 \\
\hline $\begin{array}{l}\text { Ankylosing Spondylitis not } \\
\text { Diagnosed but Descrip- } \\
\text { tion Suggestive } \ldots\end{array}$ & 11 & 11 & 0 & 11 \\
\hline $\begin{array}{c}\text { Hospital Diagnosis of } \\
\text { Rheumatoid Arthritis }\end{array}$ & 5 & 3 & 2 & 7 \\
\hline $\begin{array}{l}\text { Rheumatoid Arthritis not } \\
\text { Diagnosed but Descrip- } \\
\text { tion Suggestive } \ldots\end{array}$ & 3 & 3 & 0 & 4 \\
\hline
\end{tabular}


patients; 6 per cent. had relatives with definite ankylosing spondylitis and a further 5 per cent. had relatives probably suffering from this condition. With one exception (a nephew) the affected relatives were parents, siblings, or offspring. No enumeration of the total relatives at risk was made.

Site of Onset.-Table V shows the site of initial symptoms. Although eighteen patients had an onset diagnosed as sciatica, re-examination of their symptoms suggested that in fourteen the pain was really sacro-iliac in origin, i.e. aching pain in the lower buttocks radiating only into the upper thighs, frequently bilateral and recurring over months or years. One further patient described what was clearly pain originating from the hip joint (pain radiating down the lateral thigh to the knee, worse on hip movement and weight bearing, and associated with radiological changes in the corresponding hip joint). Only three patients described a pain that was of sciatic distribution, but unfortunately were not seen at this early stage. Although sciatica has been claimed to herald the onset of ankylosing spondylitis in about 10 per cent. of patients (Polley and Slocumb, 1947), pain of typical sciatic distribution (radiating down the posterior thigh and calf into the foot) is unusual.

19 per cent. of all patients had an extraspinal onset (initial symptoms in the hips, shoulders, peripheral joints, or heels), and a further 2 per cent. first presented with uveitis.

TABLE $V$

SITE OF INITIAL SYMPTOMS IN 222 PATIENTS WITH ANKYLOSING SPONDYLITIS

\begin{tabular}{|c|c|c|c|c|c|}
\hline \multirow{2}{*}{ Site } & & \multirow{2}{*}{\multicolumn{2}{|c|}{$\begin{array}{c}\text { No. } \\
\text { of } \\
\text { Patients }\end{array}$}} & \multicolumn{2}{|c|}{ Sex } \\
\hline & & & & Male & Female \\
\hline $\begin{array}{l}\text { Sacro-iliac joints } \\
\text { Lumbar spine .. } \\
\text { Thoracic spine . } \\
\text { Cervical spine } \\
\text { Sciatica* } \\
\text { Whole spine } \quad . \\
\text { Root joints . } \\
\text { Peripheral joints } \\
\text { Heels . } \\
\text { Iris (iritis) } \\
\text { Not stated }\end{array}$ & $\begin{array}{l}\cdots \\
\cdots \\
\cdots \\
\cdots \\
\cdots \\
\cdots \\
\cdots \\
\cdots \\
\cdots\end{array}$ & $\begin{array}{l}\cdots \\
\cdots \\
\cdots \\
\cdots \\
\cdots \\
\cdots \\
\cdots \\
\cdots \\
\cdots\end{array}$ & $\begin{array}{r}90 \\
53 \\
12 \\
9 \\
3(18)^{*} \\
1 \\
12 \\
29 \\
2 \\
6 \\
5\end{array}$ & $\begin{array}{r}70 \\
41 \\
9 \\
6 \\
3 \\
1 \\
12 \\
27 \\
2 \\
6 \\
4\end{array}$ & $\begin{array}{l}20 \\
12 \\
3 \\
3 \\
0 \\
0 \\
0 \\
2 \\
0 \\
0 \\
1\end{array}$ \\
\hline Totals & $\ldots$ & $\ldots$ & 222 & 181 & 41 \\
\hline
\end{tabular}

* Although the initial symptom was recorded as sciatica in eighteen patients, the description of the pain in fifteen suggested sacro-iliac or hip-joint pain and is entered as such.

Type of Onset.-165 patients (74 per cent.) described a gradual onset, and 45 patients ( 20 per cent.) an acute onset of symptoms. In eleven patients the type of onset was not recorded. One patient presented a picture of palindromic rheumatism for
30 years before the spondylitis was recognized (Case 2):

Case 2, a male scientist aged 55 in 1956, had suffered from attacks of synovitis at intervals of 2 or 3 years since the age of 22; initially the pain was in the right ankle and later in the knees. Between attacks he suffered only slight morning stiffness of the knees. These attacks were thought to be allergic. At the age of 51 years he first noticed pains in the chest and thoracic spine and at this time there was limitation of spinal movement and radiographs showed ankylosis of the sacro-iliac joints. Differential agglutination and erythrocyte sedimentation tests were normal. Radiotherapy gave symptomatic relief in both the spine and the knees.

Most patients with a spinal onset noticed definite aggravation of the pain after resting, pain and stiffness being most marked on rising from bed and again after reclining in an armchair in the evening. Many found relief after activity, and a few found it necessary to get out of bed during the night to "limber up" before completing their night's rest. Many, including some with quiescent disease, found that their pain was aggravated by heavy exertion or by jolting the spine.

\section{Follow-up}

The following account is based upon a study of the 212 patients whose follow-up was successful. It seems unlikely that the omission of the ten cases (eight male, two female) whose follow-up was unsuccessful, will introduce serious errors into the conclusions.

Deaths.-Seventeen patients (sixteen male and one female) are known to be dead; the causes of death are listed in Table VI (overleaf). In none was the arthritis a direct cause, but in one it was contributory (severe kyphosis with dysphagia due to a displaced aorta compressing the oesophagus), and three patients died of probable complications of the radiotherapy (leukaemia and pulmonary tuberculosis activated by deep $x$ ray).

Sites Involved in the Course of the Disease.-Table VII (overleaf) shows the frequency with which various joints were involved in the course of the disease; for this study an involved joint was defined as any joint causing symptoms with either physical signs observed at hospital or radiological changes. This definition will apply throughout this paper.

(1) Sacro-iliac Joints.-Because of our criteria for inclusion, all patients showed bilateral sacroiliac changes. While occasional cases of ankylosing spondylitis without initial sacro-iliac changes have been reported (Forestier, 1939; Oppenheimer, 1943; Hart, Robinson, Allchin, and Maclagan, 1949), such 
TABLE VI

CAUSES OF DEATH IN SEVENTEEN PATIENTS WITH ANKYLOSING SPONDYLITIS

\begin{tabular}{|c|c|c|c|c|c|}
\hline $\begin{array}{l}\text { Period of } \\
\text { First } \\
\text { Attending } \\
\text { Hospital }\end{array}$ & Patient & Sex & $\begin{array}{c}\text { Age at Death } \\
(y r s)\end{array}$ & $\begin{array}{l}\text { Duration of } \\
\text { Spondylitis } \\
\text { at Death } \\
(y r s)\end{array}$ & Cause of Death \\
\hline \multirow{8}{*}{$1940-45$} & A.O. & $\mathbf{M}$ & 57 & 30 & * Malignant tumour(?) of pleural origin \\
\hline & W.A. & $\mathbf{M}$ & 62 & 29 & *Hodgkin's disease \\
\hline & S.C. & $\mathbf{M}$ & 69 & 28 & $\begin{array}{l}\text { *Dysphagia from compression of oeso- } \\
\text { phagus by aorta } \\
\text { Inhalation pneumonia }\end{array}$ \\
\hline & J.R. & $\bar{M}$ & 55 & 26 & Street accident \\
\hline & M.B. & $\mathbf{F}$ & 37 & 23 & *Bronchiectasis and cor pulmonale \\
\hline & P.W.K. & $\mathbf{M}$ & 42 & 9 & Not known \\
\hline & C.H. & $\mathbf{M}$ & 56 & 8 & *Post-operative cerebral embolism \\
\hline & J.E.K. & $\mathbf{M}$ & 54 & $?$ & ${ }^{*}$ Fracture dislocation of spine \\
\hline \multirow{6}{*}{$1946-50$} & S.L. & $\mathbf{M}$ & 48 & 32 & *Chronic bronchitis and cor pulmonale \\
\hline & W.J. & $\mathbf{M}$ & 43 & 15 & ${ }^{*}$ Myeloid leukaemia \\
\hline & G.J. & $\mathbf{M}$ & 38 & 12 & Pulmonary tuberculosis \\
\hline & L.D. & $\mathbf{M}$ & 53 & 12 & Pulmonary tuberculosis \\
\hline & S.W. & $\mathbf{M}$ & 57 & 8 & ${ }^{*}$ Myocardial infarct \\
\hline & G.P. & $\mathbf{M}$ & 35 & 6 & Pulmonary tuberculosis \\
\hline \multirow{3}{*}{$1951-55$} & A.E. & $\mathbf{M}$ & 69 & 53 & * Carcinoma of pancreas \\
\hline & J.B. & $\mathbf{M}$ & 61 & 37 & Myocardial infarct \\
\hline & A.R. & $\mathbf{M}$ & 57 & 22 & Carcinoma of stomach \\
\hline
\end{tabular}

TABLE VII

BONE AND JOINT LESIONS FOUND DURING FOLLOW-UP IN 212 PATIENTS WITH ANKYLOSING SPONDYLITIS

\begin{tabular}{|c|c|c|c|c|c|c|}
\hline \multirow{2}{*}{\multicolumn{4}{|c|}{ Site of Lesions }} & \multirow{2}{*}{$\begin{array}{c}\begin{array}{c}\text { Total } \\
\text { No. of } \\
\text { Patients }\end{array} \\
212\end{array}$} & \multicolumn{2}{|c|}{ Sex } \\
\hline & & & & & $-\frac{1}{173}$ & $\begin{array}{c}\text { Female } \\
39\end{array}$ \\
\hline 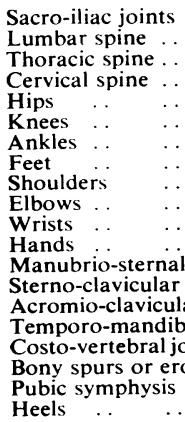 & $\begin{array}{l}\ldots \\
\ldots \\
\ldots \\
\ldots \\
\ldots \\
\ldots \\
\ldots \\
\ldots \\
\ldots \\
\ldots \\
\text { nts } \\
\text { oits } \\
\text { oints } \\
\text { joints } \\
\text { s.. } \\
\text { ns } \\
\ldots \\
\ldots\end{array}$ & $\begin{array}{l}\cdots \\
\cdots \\
\cdots \\
\cdots \\
\cdots \\
\cdots \\
\cdots \\
\cdots \\
\cdots \\
\cdots \\
\cdots \\
\cdots \\
\cdots \\
\cdots \\
\cdots \\
\cdots\end{array}$ & 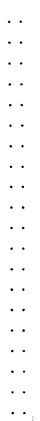 & $\begin{array}{r}212 \\
186 \\
156 \\
110 \\
71 \\
34 \\
15 \\
24 \\
35 \\
12 \\
10 \\
14 \\
10 \\
4 \\
4 \\
1 \\
47 \\
52 \\
43 \\
5\end{array}$ & $\begin{array}{r}173 \\
152 \\
125 \\
92 \\
63 \\
29 \\
12 \\
21 \\
30 \\
9 \\
8 \\
11 \\
8 \\
4 \\
4 \\
1 \\
40 \\
45 \\
38 \\
4\end{array}$ & $\begin{array}{r}39 \\
34 \\
31 \\
18 \\
8 \\
5 \\
3 \\
3 \\
5 \\
3 \\
2 \\
3 \\
2 \\
0 \\
0 \\
0 \\
7 \\
7 \\
5 \\
1\end{array}$ \\
\hline
\end{tabular}

cases must be rare and difficult to diagnose with confidence until sacro-iliac changes become manifest.

In our experience, early changes in the sacro-iliac joints are better shown by the anteroposterior view than by oblique views. Indeed, the latter may prove misleading, for seven of the present cases showed no abnormality on oblique views at a time when changes were suspected on the anteroposterior view (Fig. 1, opposite).

The subsequent course and radiographs confirmed the diagnosis in all seven cases. In doubtful cases, Romanus and Ydén (1955) found the posteroanterior view of value.

(2) Spinal Involvement.-The extent of spinal involvement is greater in those with long-lasting disease (Table VIII, opposite).

The thoracic and lumbar spine shows the same trend with duration of disease as the cervical spine. At follow-up, in only sixteen patients, mostly cases of relatively short duration (mean 6.2 years, standard deviation 3.8 years), was the disease confined to the sacro-iliac joints.

Although the disease seems to spread up the spine, we have observed, as have other writers (Borak, 1946), that the vertebral erosions (or "anterior 


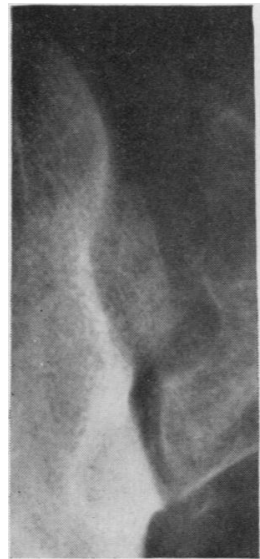

(a)

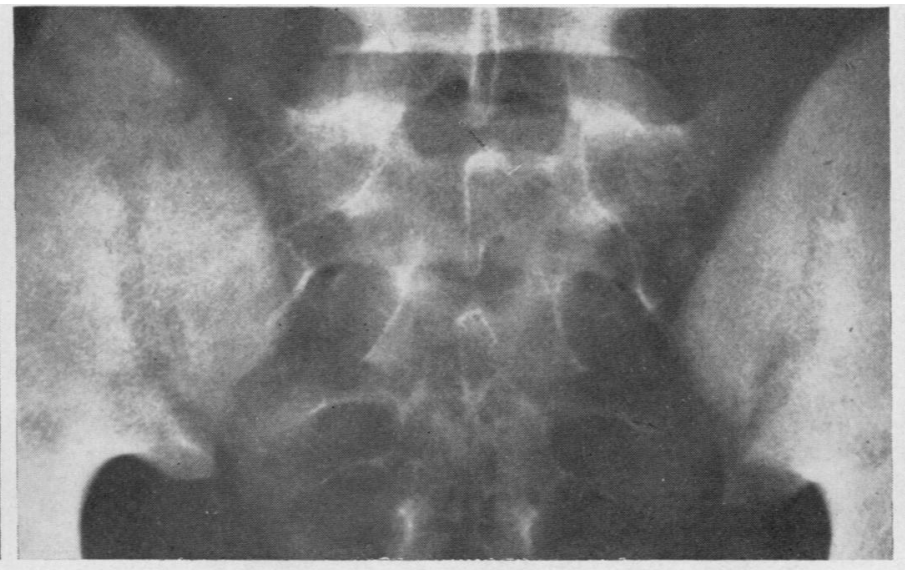

(b)

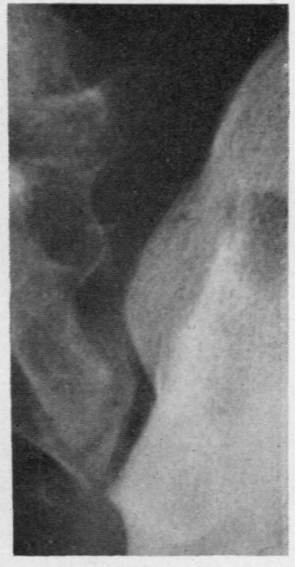

(c)

Fig. 1.-Ankylosing spondylitis of 4 months' duration. Antero-posterior view of sacro-iliac joints (a) shows loss of definition of articular margins and erosions, especially on the left side. Oblique views $(b$ and $c$ ) were then normal but showed erosions at a later stage.

TABLE VIII

FREQUENCY OF SPINAL, ROOT JOINT, AND PERIPHERAL JOINT INVOLVEMENT AT LAST EXAMINATION CORRELATED WITH DURATION OF SYMPTOMS IN 211* PATIENTS WITH ANKYLOSING SPONDYLITIS, FOLLOWED UP UNTIL DEATH OR TO THE PRESENT TIME

\begin{tabular}{|c|c|c|c|c|c|c|}
\hline \multirow{2}{*}{$\begin{array}{c}\text { Total Duration } \\
\text { of Symptoms } \\
\text { (yrs) }\end{array}$} & \multirow{2}{*}{$\begin{array}{l}\text { Total No. of } \\
\text { Patients in } \\
\text { Each Group }\end{array}$} & \multicolumn{5}{|c|}{ Percentage of Patients in Each Group with Involvement of: } \\
\hline & & $\begin{array}{l}\text { Cervical } \\
\text { Spine }\end{array}$ & $\begin{array}{c}\text { Thoracic } \\
\text { Spine }\end{array}$ & $\begin{array}{l}\text { Lumbar } \\
\text { Spine }\end{array}$ & $\begin{array}{l}\text { "Root" } \\
\text { Joints }\end{array}$ & $\begin{array}{l}\text { Peripheral } \\
\text { Joints }\end{array}$ \\
\hline $\begin{array}{r}1-5 \\
6-10 \\
11-15 \\
16-20 \\
\text { Over } 20\end{array}$ & $\begin{array}{l}30 \\
53 \\
54 \\
27 \\
47\end{array}$ & $\begin{array}{l}27 \\
42 \\
50 \\
74 \\
68\end{array}$ & $\begin{array}{l}57 \\
57 \\
80 \\
92 \\
96\end{array}$ & $\begin{array}{r}70 \\
81 \\
91 \\
100 \\
94\end{array}$ & $\begin{array}{l}27 \\
40 \\
41 \\
41 \\
45\end{array}$ & $\begin{array}{l}17 \\
28 \\
13 \\
30 \\
36\end{array}$ \\
\hline
\end{tabular}

* In one further patient, omitted from this Table, the duration of symptoms was not known.

spondylitis" of Romanus and Ydén, 1955) and the disk ossification usually make their first appearance in the lower thoracic and upper lumbar spine (Fig. 2, overleaf). Although anterior spondylitis was observed infrequently ( 23 per cent. of those with $x$ rays available for review), this was probably because many patients were spondylitics of long standing and radiographs of early lesions were not always available.

In some cases anterior spondylitis was seen in the cervical region, and one case (A.H.) is of outstanding interest since the upper five cervical vertebrae were fused as well as the lowest ones (Fig. 3, overleaf). Movement could therefore only take place to a very limited extent at C 6-7 and this is where the anterior erosion occurred. The fusion always seems to be associated with sclerosis and it may possibly be an aseptic pressure-necrosis of bone. It is worth noting that, in the spine, disk degeneration may occur before ossification of the disk edge and ligaments, giving an $x$-ray appearance of osteophytosis affecting one or more vertebrae (Fig. 4, overleaf).

The costovertebral joints were radiologically involved in 47 patients and two of these showed ossification of the capsules of the first costovertebral joints (Fig. 5, overleaf).

(3) "Root Joint" Involvement.-This is taken to mean involvement of the hips or shoulders. 83 (39 per cent.) of the patients showed involvement of either or both of these joints. Rather surprisingly there was little greater incidence of root joint involvement in cases seen after the first 10 years of spondylitic symptoms (Table VIII). 50 per cent. of those patients in whom the disease began before the age of 20 years showed root joint involvement compared with 36 per cent. of those with a later onset. However, this difference does not quite reach significant levels. 


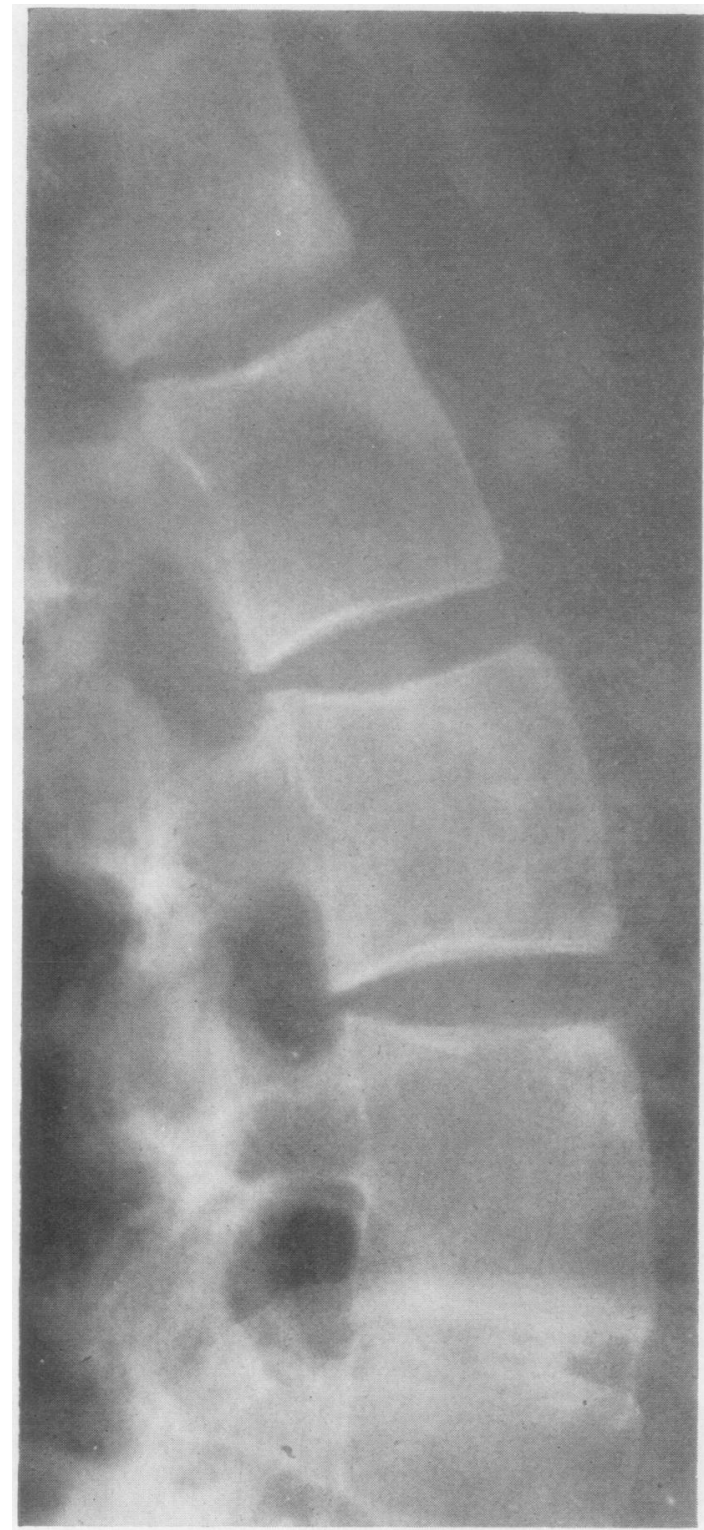

Fig. 2.-“Anterior spondylitis". Erosions of anterior angles of vertebral bodies progressing to a stage of healing with sclerosis (adjoining top intervertebral disk), and still later to ossification in the disk edge (bottom intervertebral disk).

(4) Peripheral Joints.-Fifty patients (24 per cent.) showed involvement of the peripheral joints (excluding hips and shoulders) at some stage in the illness. Other writers have reported an incidence of peripheral joint involvement as high as 75 per cent. (Romanus and Ydén, 1955); this figure, however,

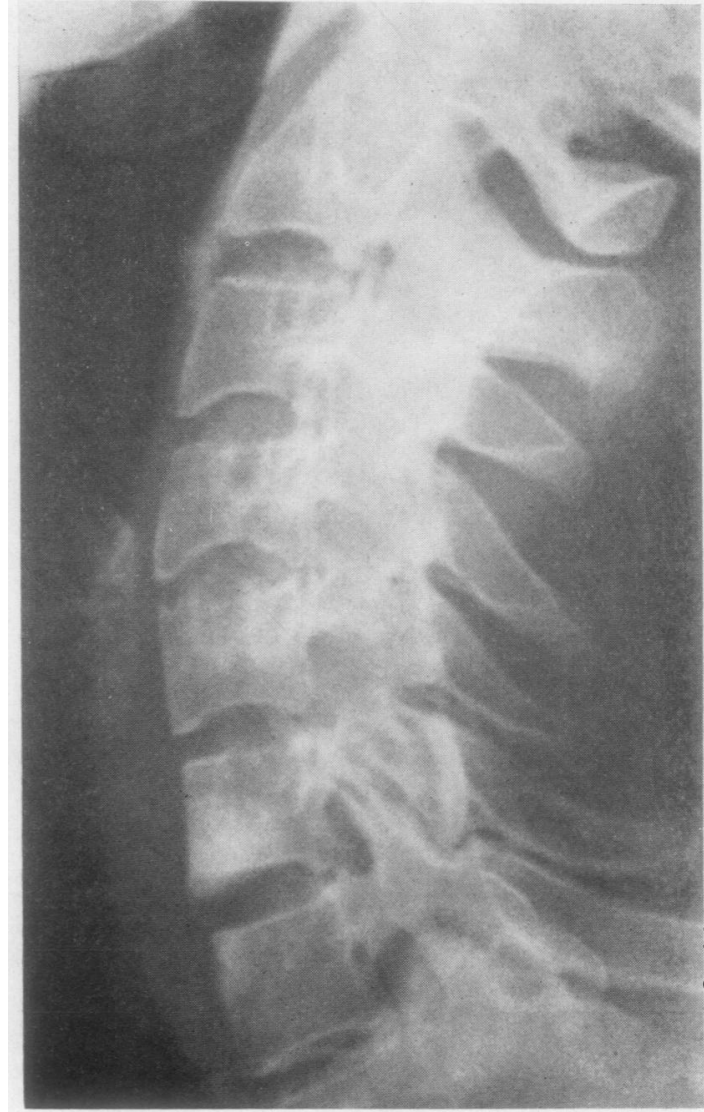

Fig. 3.- “Anterior spondylitis" in the cervical spine.

obviously depends upon the author's definition of "joint involvement".

As with the root joints there was little change in the incidence of peripheral joint involvement in those who had had spondylitic symptoms for more than 10 years (Table VIII). The incidence of peripheral joint involvement in spondylitics with onset before the age of 20 years was $\mathbf{4 0}$ per cent. compared with 22 per cent. in those with an onset after that age. This difference is significant at the 5 per cent. level.

(5) Extra-Articular Bone Lesions.-Approximately one-quarter of the patients showed osteolytic lesions or what is presumably the healed stage of such lesions-areas of irregular cortical bone at one or more sites around the pelvis, upper femora, or feet (Table IX, opposite). The ischial tuberosities were the commonest sites for such lesions and, except in one case, these lesions were not seen at other sites 


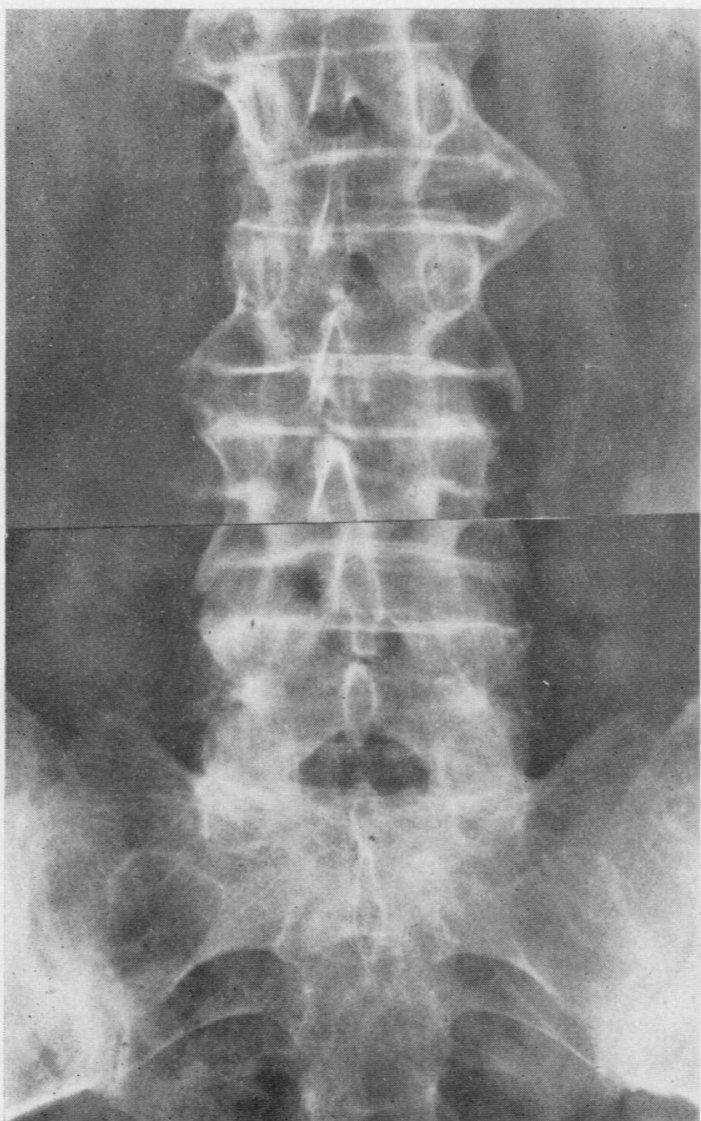

Fig. 4.-Ankylosing spondylitis in a woman of 34 years. Intervertebral disk degeneration has preceded ossification, giving an appearance resembling osteophytosis of the lumbar spine. The sacro-iliac joints are eroded and sclerosed.

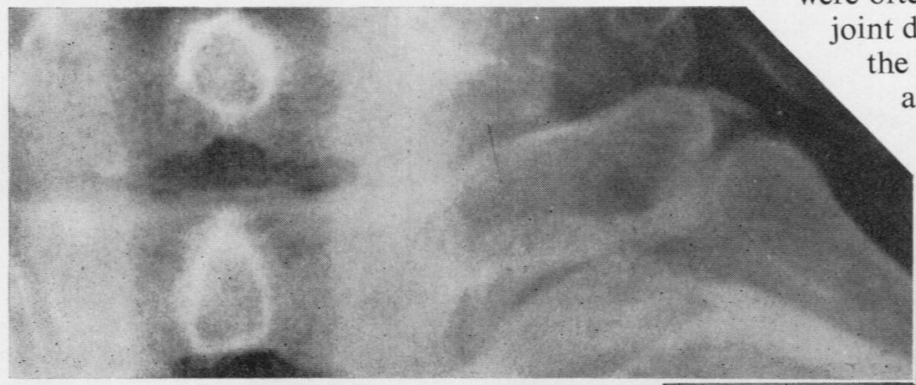

Fig. 5.-Ossification of capsule of first costotransverse joint in ankylosing spondylitis.

Fig. 6.-Erosion of ischial tuberosity and symphysis pubis in ankylosing spondylitis.
TABLE IX

FREQUENCY OF EXTRA-ARTICULAR BONE LESIONS FOUND DURING FOLLOW-UP IN 212 PATIENTS WITH ANKYLOSING SPONDYLITIS

\begin{tabular}{|c|c|c|c|c|c|c|c|}
\hline \multicolumn{6}{|c|}{ Site } & \multicolumn{2}{|c|}{ No. of Patients } \\
\hline Ischium & $\begin{array}{l}\text { Left s } \\
\text { Great } \\
\text { Right } \\
\text { Great } \\
\text { Bilate }\end{array}$ & $\begin{array}{l}\text { ide onl } \\
\text { er on } 1 \\
\text { side or } \\
\text { er on } r \\
\text { ral and }\end{array}$ & $\begin{array}{l}\text { y.. } \\
\text { eft } \\
\text { ight } \\
\text { ight } \\
\text { equal }\end{array}$ & $\begin{array}{l}\cdots \\
\cdots \\
\cdots \\
\cdots\end{array}$ & $\begin{array}{l}\ldots \\
\cdots \\
\cdots \\
\cdots\end{array}$ & $\left.\begin{array}{r}12 \\
7 \\
2 \\
4 \\
25\end{array}\right\}$ & 50 \\
\hline $\begin{array}{l}\text { Iliac cres } \\
\text { Greater t } \\
\text { Lesser tr } \\
\text { Heel } \\
\text { Medial c } \\
\text { Medial n }\end{array}$ & $\begin{array}{l}\text { hanter } \\
\text { anter } \\
\text { id of fo } \\
\text { eolus of }\end{array}$ & $\begin{array}{l}\ldots \\
\cdots \\
\cdots \\
\text { ot } \\
\text { tibia }\end{array}$ & $\begin{array}{l}\cdots \\
\cdots \\
\cdots \\
\cdots\end{array}$ & $\begin{array}{l}\ldots \\
\cdots \\
\cdots \\
\cdots\end{array}$ & $\begin{array}{l}\cdots \\
\ldots \\
\ldots \\
\cdots\end{array}$ & & $\begin{array}{r}14 \\
3 \\
5 \\
5 \\
1\end{array}$ \\
\hline
\end{tabular}

around the pelvis in the absence of ischial lesions. These erosions rarely occurred early in the course of the disease and were only occasionally of diagnostic help, e.g. in cases with doubtful $x$-ray changes, in the sacro-iliac joints. Since all these lesions lie close to tendon insertions it might be expected that they were due to abnormal strains at these sites, possibly because of the rigid spine. However, of the fifty patients with ischial tuberosity lesions, only 42 had an immobile or severely restricted thoraco-lumbar spine. Two patients with huge ischial erosions (Fig. 6) had only slight limitation of spinal movement, and three patients had none. One patient, a schoolboy, developed ischial erosions soon after a period of prolonged immobilization. Clearly, neither a rigid spine nor physical activity are essential for the production of ischial erosions. The predominance of ischial lesions on the left side was unexpected (Table IX).

Spurs of bone along the iliac crests and trochanters were often but not invariably associated with hip joint disease. The lesions behind and beneath the heels, though uncommon, were clinically and radiologically identical with those seen in patients with rheumatoid arthritis (Bywaters, 1954).

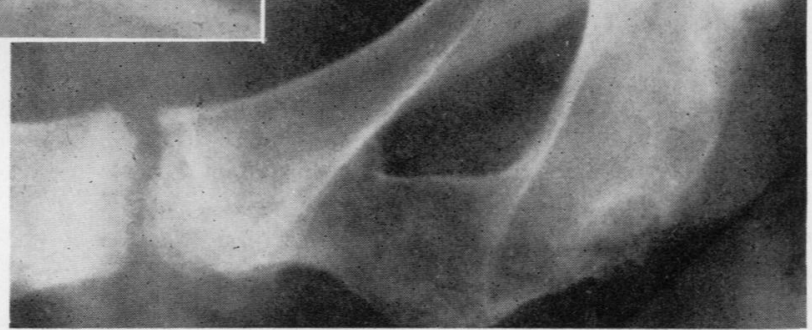




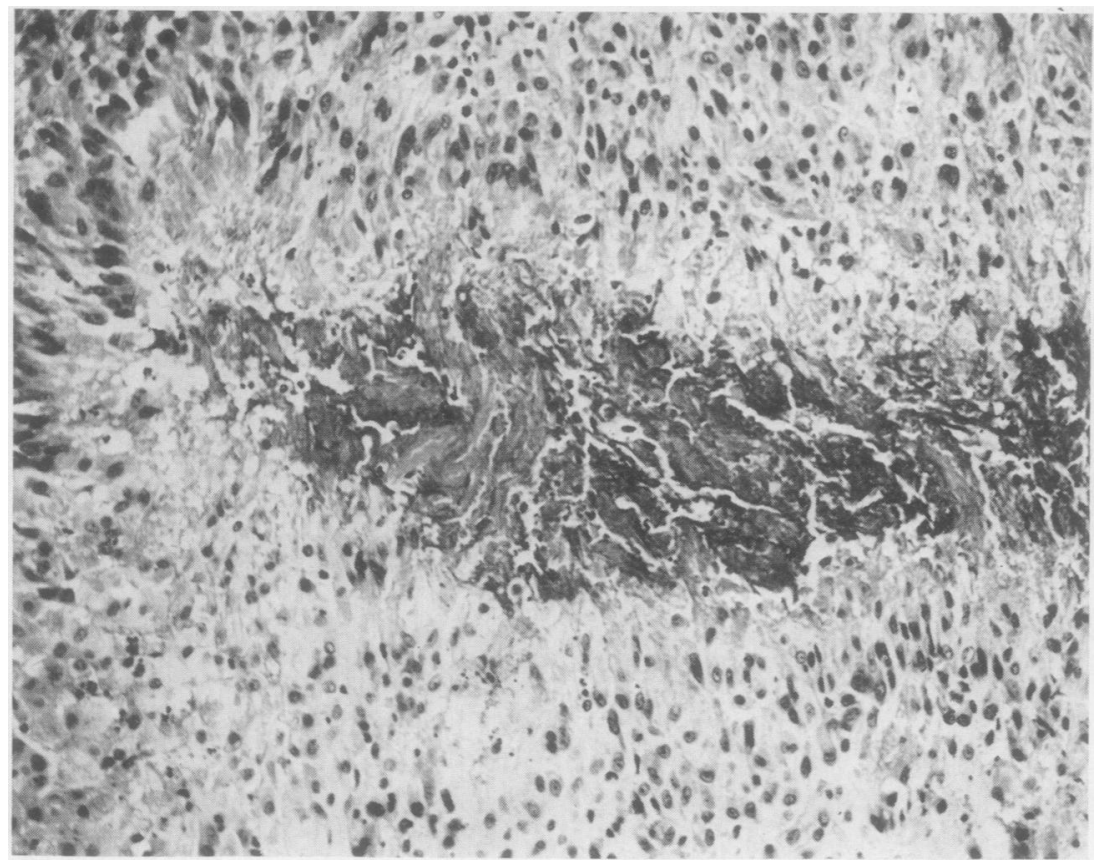

Fig. 7.-Subcutaneous nodule from a patient with ankylosing is spondylitis and extensive peripheral arthritis.

Haematoxylin and eosin $\times 200$.

(6) Subcutaneous Nodules.-One man with severe peripheral joint involvement (Case 3 ) developed multiple subcutaneous nodules identical clinically and histologically with those seen in rheumatoid arthritis (Fig. 7). This association has been reported once before (Smythe, 1956).

Case 3, an ex-lorry driver aged 69 in 1955, suffered an attack of "lumbago and sciatica" for one week at the age of 40 years, and then remained well until 7 years later when he complained of pain and stiffness in the neck. When aged 53 years he attended hospital and ankylosing spondylitis was diagnosed. The disease was then confined to the spine and root joints. Not until the age of 64 years did peripheral joint involvement occur and this progressed rapidly so that, at the time of his death at the age of 69 , he showed severe deformity of all joints. including the fingers and toes; and multiple subcutaneous nodules. The sheep cell agglutination test was repeatedly negative. Radiographs and post-mortem examination confirmed the spondylitis and showed peripheral joint changes indistinguishable from those of theumatoid arthritis. Necrobiotic nodules were also present in the pericardium.

One other patient showed a subcutaneous nodule but this was of the rheumatic fever variety and occurred during an attack of acute polyarthritis that was probably coincidental rheumatic fever:

Case 4, a male hairdresser aged 43 years in 1956, had suffered an attack of rheumatic fever lasting 3 months at the age of 11 years, and was thought to have had cardiac involvement. He then remained well until the age of 35 when a further attack of polyarthritis occurred soon after a sore throat. When he was seen 3 mont later only an apical systolic murmur was hearf. Arthralgia continued with low back pain and stiffnes? and after a further 3 months an $x$ ray showed bilaterat $\bar{\partial}$ sacro-iliitis. The erythrocyte sedimcntation rate (Westergrcn) was then $16 \mathrm{~mm}$./hr. A subcutaneous nodule $\frac{0}{D}$ excised from over the sacrum was histologically typical of the rheumatic fever variety. When he was last seen in 1956, this patient had a rigid spine with only slight discomfort. The erythrocyte sedimentation rate and differential agglutination test then were normal.

Functional State.-On the basis of their working capacity and mobility at the time of follow-up, all the living patients were placed in one of five functional grades (Fig. 8, opposite), and this was correlated with the duration of symptoms. The slow decrease in functional capacity in the group with increasing duration of the disease is well shown, but it is interesting that 63 per cent. of the patients seen after more than 20 years of illness were working, admittedly in light occupations, and were supporting themselves and their families. After the same period only 12 per cent. of the patients were bedridden or chairbound, though even in this group a few strong- $\omega$ willed individuals did part-time work in the home or attended an office in a wheel chair. There was 0 no evidence that females were any less disabled by the disease than were males.

Employment.-To some extent, the spondylitic may mask his functional deterioration by changing to a 


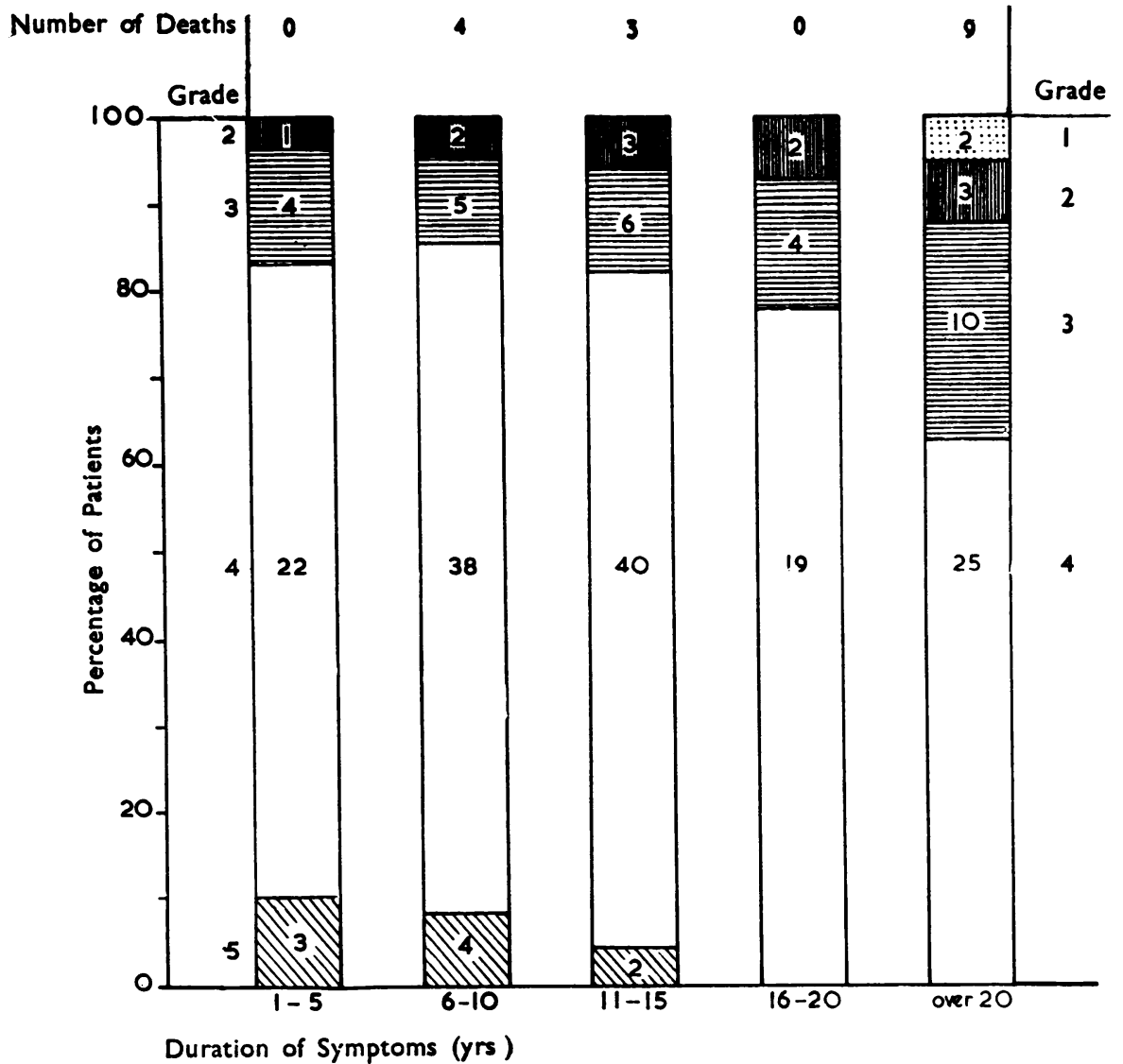

Fig. 8. - Functional status of 211 patients with ankylosing spondylitis of varying durations, graded in order of incapacity as follows:

(5) Completely normal. Full-time work and physical recreations without symptoms.

(4) Almost normal. Full-time work but symptoms after physical exertion.

(3) Mobile but unable to work full time.

(2) Chair-bound.

(1) Bedridden.

Deaths are recorded above each column according to duration of symptoms at time of death. One death was omitted because the duration of illness was not known.

lighter occupation. Fig. 9 (overleaf) shows occupational data on the patients followed-up. After more than 20 years of spondylitic symptoms only 27 per cent. of forty patients were unemployed and a further 20 per cent. had changed or modified their employment because of the spondylitis. The apparent improvement in working capacity after 10 years of illness is probably not significant when one considers that nine of the seventeen deaths occurred in patients with spondylitis of greater than 20 years' duration.

Deformity.-Four grades of deformity were recognized (Fig. 10, overleaf). Here again there was a worsening in groups of longer duration.

Despite the few severely-deformed patients who continued to work, there was, as might be expected, a correlation between functional capacity and deformity; 91 per cent. of the patients with no deformity were at work when last seen, whereas only 31 per cent. of the severely-deformed patients were working.

Chest Expansion.-A reduced chest expansion is an early and valuable sign of ankylosing spondylitis (Hart, Bogdanovitch, and Nichol, 1950). Of the patients who had had symptoms for 5 years or less, 81 per cent. had a chest expansion of 2 in. or less and 19 per cent. of less than 1 in. After more than 20 years of spondylitis, the corresponding figures were 96 and 62 per cent.

Erythrocyte Sedimentation Rate.-Opinions vary as to the value of the erythrocyte sedimentation rate as 


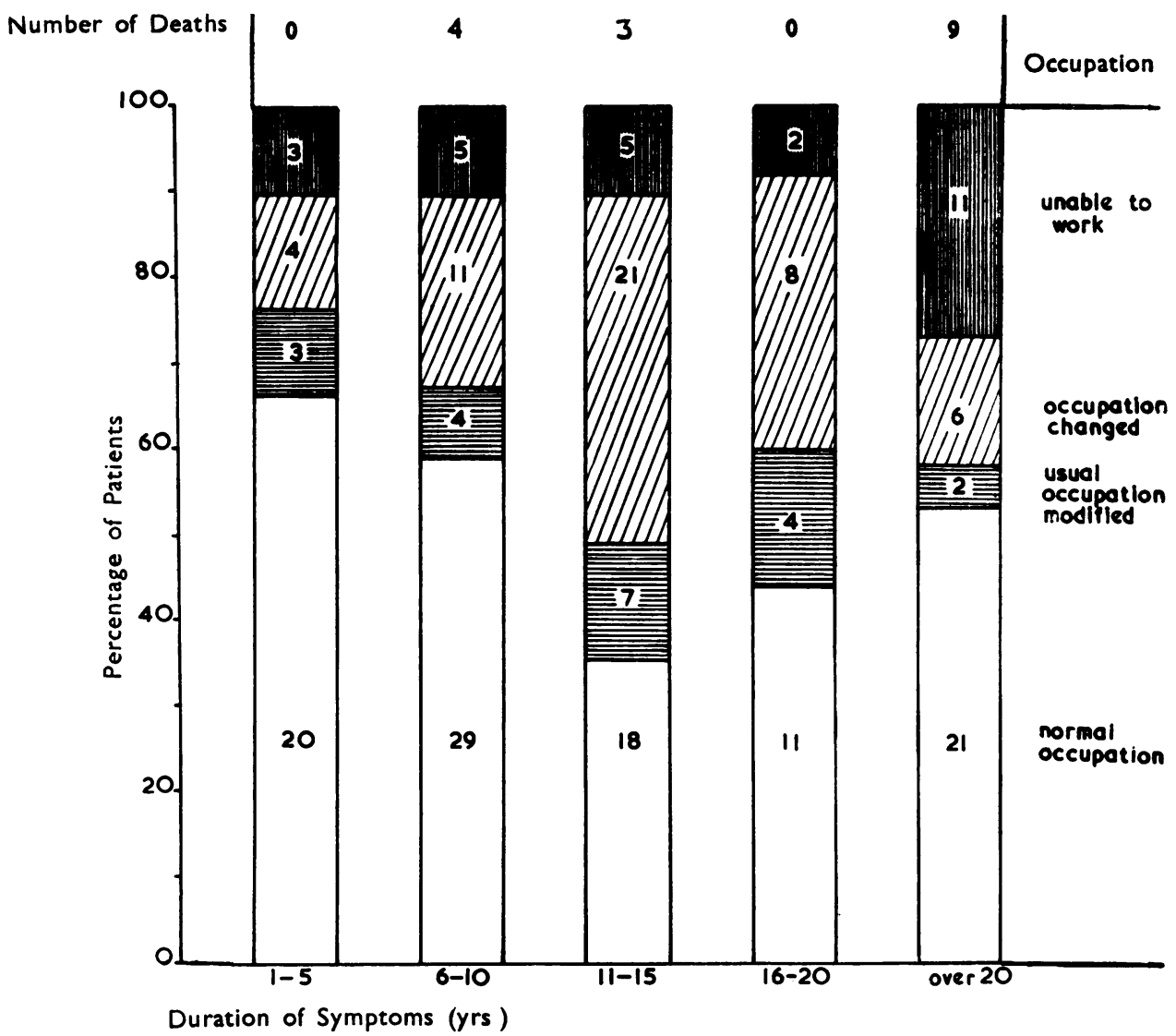

Fig.9.-Occupational data on 211 patients with ankylosing spondylitis of varying durations. Deaths are shown above each column as in Fig. 8

an index of active disease in ankylosing spondylitis, but most agree that it is not invariably accelerated. It was estimated (by the Westergren method) at follow-up in 138 of the present patients, and was found to be $15 \mathrm{~mm}$./ hr or more in 64 patients (48 per cent. of those tested). This proportion did not vary significantly with the duration of symptoms for the series as a whole, nor did the mean rate differ significantly between the five duration groups (Table X).

TABLE $\mathbf{X}$

AVERAGE ERYTHROCYTE SEDIMENTATION RATE (WESTERGREN) FOR GROUPS OF PATIENTS WITH ANKYLOSING SPONDYLITIS OF VARYING DURATIONS

\begin{tabular}{c|c|c}
\hline $\begin{array}{c}\text { Total Duration of } \\
\text { Symptoms } \\
\text { (yrs) }\end{array}$ & $\begin{array}{c}\text { No. of Patients } \\
\text { Tested }\end{array}$ & $\begin{array}{c}\text { Average E.S.R. } \\
(\mathrm{mm} . / \mathrm{hr})\end{array}$ \\
\hline $1-5$ & 19 & 26 \\
$6-10$ & 33 & $20 \cdot 2$ \\
$11-15$ & 34 & $22 \cdot 5$ \\
$16-20$ & 26 & $23 \cdot 2$ \\
Over 20 & 27 & $17 \cdot 3$ \\
\hline
\end{tabular}

In individual cases, however, it fluctuated considerably during the course of the disease, usually in parallel with the clinical state and treatment (Fig. 11, opposite). This differs somewhat from the finding of Blumberg and Ragan (1956) that the "average" rate for a group of spondylitics is very high in the first 2 years of the illness, falling rapidly towards normal thereafter. This discrepancy may be due to the small number of spondylitics of very recent onset in the present series, and perhaps to the fact that peripheral joint involvement, with which the erythrocyte sedimentation rate is high, not infrequently brings the patient to hospital early in $\mathcal{N}$ the course of his disease. In the present series, N 28 well-documented patients had the erythrocyte $N$ sedimentation rate estimated early in their illness at the time of active peripheral joint disease, and the mean value was $65.2 \mathrm{~mm}$. $/ \mathrm{hr}$ (standard deviation $\stackrel{\varrho}{=}$ $\pm 31 \cdot 3$ ), which is considerably higher than that for $\stackrel{\Phi}{?}$ the whole series. Indeed, it is exceptional to find a rate above $40 \mathrm{~mm} . / \mathrm{hr}$ at any stage if the disease is confined to the spine. 


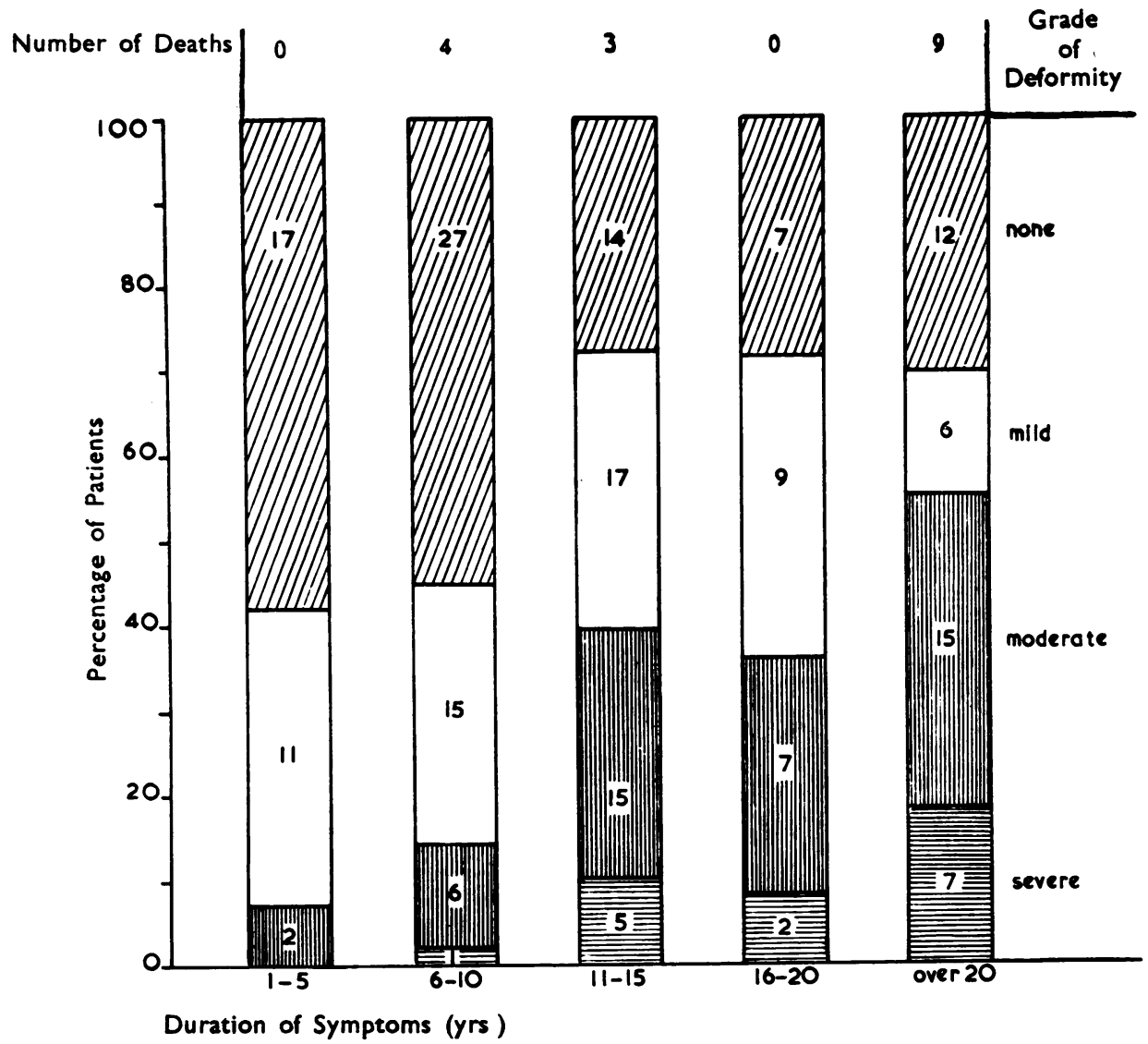

Fig. 10.-Deformity in 211 patients with ankylosing spondylitis of varying durations, graded in order of severity as follows:

(4) None.

(3) Mild. Slight kyphosis of thoracic and/or flattening of

lumbar spine.

(2) Moderate. Severe kyphosis or peripheral joint deformity but still mobile.

(1) Severe. Grossly kyphotic spine and/or hip joint flexion deformity, sufficient to prevent ambulation.

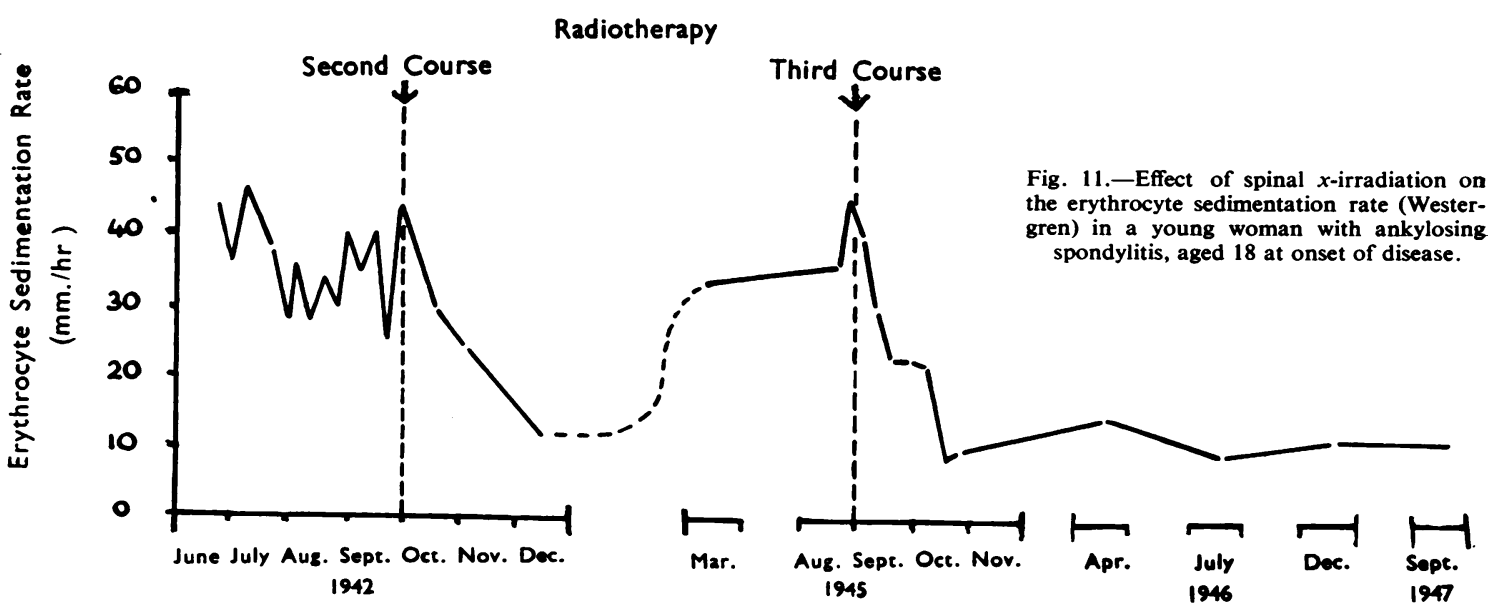


The 138 cases in which the rate was measured, were classified as active or inactive at follow-up on the basis of symptoms and/or changing physical and radiological signs. Of the 35 patients considered to have active disease, 29 ( 83 per cent.) had an abnormal rate $(15 \mathrm{~mm}$./ $/ \mathrm{hr}$ or more), whereas sixty (58 per cent.) of 103 patients thought to have inactive spondylitis had a normal rate. Thus there was fair agreement between the clinical impression and the erythrocyte sedimentation rate in clearly active cases, but the agreement was much less satisfactory when the clinical impression suggested inactive spondylitis.

Flocculation Tests. - 33 patients had various flocculation tests performed, usually including thymol turbidity, zinc sulphate turbidity, and colloidal gold tests, as well as a serum protein estimation. The results were normal except for three patients who showed hyperglobulinaemia and active spondylitis with peripheral joint involvement.

Sheep Cell Agglutination Test.-These were performed in 75 cases. In one (D.T.) male the titre was $1: 32$, but a repetition gave a negative result, and in another male (S.F.) it was $1: 1,024$ and had not been repeated. The latter patient had peripheral joint involvement but no subcutaneous nodules. In all other cases the result of this test was negative.

Synovial Fluid.-Synovial fluid from eight patients was examined and the changes found were similar to those associated with rheumatoid arthritis. The protein content ranged from $1 \cdot 25$ to $7 \cdot 3 \mathrm{~g}$. per cent. and the cell count from 3,300 to $23,000 / \mathrm{c}$. mm. with a predominance of polymorphs in all except one case. Only one viscosity measurement was made and this was low.

Radiotherapy.-This was given to 200 patients and 91 of these received multiple courses. Though treatment was not standardized, most patients received total skin dosages ranging from 1,000 to 2,000 r to each of four or five spinal fields. $X$ rays were generated at 200 or $250 \mathrm{kV}$. with filters of $1 \mathrm{~mm}$. copper and $1 \mathrm{~mm}$. aluminium, and the focus-skin distance was $5 \mathrm{~cm}$. Treatment was given over a period of approximately 3 weeks. The peripheral joints usually received considerably smaller dosages. The overall symptomatic results in the first 6 months after treatment are shown in Table XI.

Failure to respond to radiotherapy did not separate out a group of spondylitics with atypical features as suggested by Sharp and Easson (1954), but rather a group of patients with more extensive disease and particularly with peripheral joint involvement (Table XII). Radiotherapy to the root
TABLE XI

RESULTS OF RADIOTHERAPY APPROXIMATELY 6 MONTHS AFTER TREATMENT IN 200 PATIENTS WITH ANKYLOSING SPONDYLITIS

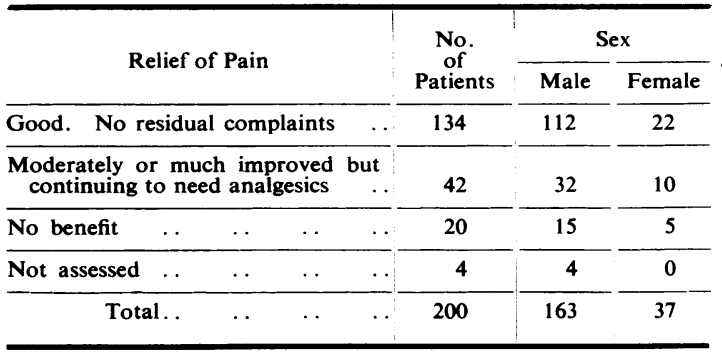

and peripheral joints was certainly not as consis- ?? tently beneficial as spinal irradiation. Of 51 patients $\vec{V}$ given treatment to the root or peripheral joints, i 27 obtained good relief of pain, twenty moderate relief, and four no relief. In 25 patients there was residual or even progressive limitation of joint movement after radiotherapy.

TABLE XII

FACTORS AFFECTING RESPONSE TO RADIOTHERAPY IN 196 CASES OF ANKYLOSING SPONDYLITIS

\begin{tabular}{|c|c|c|c|c|c|c|}
\hline \multirow{3}{*}{ Factors Investigated } & \multicolumn{4}{|c|}{ Degree of Therapeutic } & Benef & \\
\hline & \multicolumn{2}{|c|}{ Good } & \multicolumn{2}{|c|}{ Moderate } & \multicolumn{2}{|c|}{ None } \\
\hline & No. & $\begin{array}{c}\text { Per } \\
\text { cent. }\end{array}$ & No. & $\begin{array}{c}\text { Per } \\
\text { cent. }\end{array}$ & No. & $\begin{array}{l}\text { Per } \\
\text { cent. }\end{array}$ \\
\hline $\begin{array}{l}\text { Lumbar spine involved } \\
\text { Thoracic spine involved } \\
\text { Cervical spine involved } \\
\text { Root joints involved } \\
\text { Peripheral joints involved } \\
\text { Iritis present .. . . }\end{array}$ & $\begin{array}{r}109 \\
91 \\
48 \\
48 \\
23 \\
37\end{array}$ & $\begin{array}{l}81 \\
68 \\
36 \\
35 \\
17 \\
27\end{array}$ & $\begin{array}{r}40 \\
34 \\
30 \\
23 \\
14 \\
5\end{array}$ & $\begin{array}{l}95 \\
81 \\
70 \\
55 \\
33 \\
12\end{array}$ & $\begin{array}{r}20 \\
16 \\
14 \\
9 \\
7 \\
8\end{array}$ & $\begin{array}{r}100 \\
80 \\
70 \\
45 \\
35 \\
40\end{array}$ \\
\hline Total No. of Cases & 134 & & 42 & & 20 & \\
\hline $\begin{array}{c}\begin{array}{c}\text { No. in Each } \\
\text { who hategory } \\
\text { Multiple }\end{array} \\
\text { Courses } \\
\end{array}$ & 49 & 36 & 31 & 74 & 11 & 55 \\
\hline $\begin{array}{l}\text { Mean Duration of } \\
\text { Symptoms at Time of } \\
\text { First } X \text { Ray } \ldots\end{array}$ & & $\cdot 5$ & & 8 & & .5 \\
\hline
\end{tabular}

While of value in the relief of pain, radiotherapy $\frac{7}{0}$ rarely restores restricted movement (Desmarais, 1953), nor does it prevent further exacerbations. N Table XIII (opposite) shows the proportion of $N$ patients developing further evidence of active disease after radiotherapy. As a measure of activity, all ${ }^{\omega}$ patients who suffered from further pain requiring analgesics for more than one month were considered ${ }^{\circ}$ to have relapsed. It was disappointing to find that only 43 per cent. of patients were not requiring regular analgesics within one year after treatment had been completed. Although many patients will em- $\frac{}{\Phi}$ 
phatically state that pain is less after radiotherapy, a more objective means of assessment such as an analgesic consumption may be a better index of improvement. By 10 years after radiotherapy only 22 per cent. of the patients followed for that period could claim no further recourse to analgesic drugs. It should be emphasized that a number of these patients gained a further remission either spontaneously or after further radiotherapy.

TABLE XIII

LONG-TERM RESULTS OF RADIOTHERAPY IN 183 PATIENTS WITH ANKYLOSING SPONDYLITIS

The results apply to each patient's first course of therapy only.

\begin{tabular}{c|c|c}
\hline $\begin{array}{c}\text { Duration of Time } \\
\text { since Therapy (yrs) }\end{array}$ & $\begin{array}{c}\text { Percentage } \\
\text { Pain-Free }\end{array}$ & $\begin{array}{c}\text { No. of Patients } \\
\text { in Group }\end{array}$ \\
\hline 1 & $42 \cdot 6$ & 183 \\
2 & $36 \cdot 4$ & 173 \\
3 & $33 \cdot 1$ & 142 \\
4 & $27 \cdot 6$ & 123 \\
5 & $26 \cdot 3$ & 99 \\
10 & $21 \cdot 8$ & 78 \\
Over 10 & 10 & 20 \\
\hline
\end{tabular}

Complications of radiotherapy were infrequent and consisted of menstrual disturbances, which progressed to permanent amenorrhoea in six out of 19 patients, sterility and testicular atrophy in one patient, possible activation of pulmonary tuberculosis in two patients, and myeloid leukaemia in one patient. The last three patients eventually died.

\section{Complications}

(1) Uveitis. -56 patients (25 per cent.) gave a history of treatment for uveitis at an ophthalmic clinic or were found to have evidence of past uveitis, i.e. posterior synechiae. Seven of the patients with synechiae could remember no inflammation of the eyes. No band opacities were seen.

Although it has been reasonably claimed that the incidence of uveitis increases with the duration of follow-up (Hart and Maclagan, 1955), there was no evidence of this in the present series beyond the 10-year mark (Table XIV).

$$
\text { TABLE XIV }
$$

INCIDENCE OF UVEITIS IN RELATION TO DURATION OF ANKYLOSING SPONDYLITIS IN 211* CASES ADEQUATELY FOLLOWED UP

\begin{tabular}{cc|c}
$\begin{array}{c}\text { Duration of } \\
\text { Symptoms (yrs) }\end{array}$ & $\begin{array}{c}\text { No. of Patients } \\
\text { in Each Group }\end{array}$ & $\begin{array}{c}\text { Percentage of } \\
\text { Patients with Uveitis }\end{array}$ \\
\cline { 1 - 2 } $1-5$ & 30 & 17 \\
$6-10$ & 53 & 34 \\
$11-15$ & 54 & 28 \\
$16-20$ & 27 & 30 \\
Over 20 & 47 & 26 \\
\hline
\end{tabular}

* One patient has been omitted because duration of illness was not known.
In most cases the uveitis was unilateral, often recurrent but sometimes involving each eye alternately. In four patients uveitis preceded other manifestations of spondylitis by 1 to 9 years. Uveitis first occurred in all adequately-documented cases within 10 years of the initial symptoms. There seemed to be no correlation between the attacks of uveitis and the activity of the spondylitis and four patients, whose arthritis had apparently been inactive for several years, continued to have attacks of uveitis.

Only two patients suffered serious visual impairment and one other required an iridectomy.

Uveitis occurred in 36 per cent. of those patients with peripheral joint lesions and in 21 per cent. of those without, a difference that just reaches the 5 per cent. level of significance.

The frequency of uveitis is thus about six times that found in rheumatoid arthritis (Sorsby and Gormaz, 1946), so that a history of iritis or the presence of posterior synechiae is of considerable diagnostic importance in any obscure case of backache.

(2) Chest Complications.-The clinical diagnoses of those patients with pulmonary complications are listed in Table XV. These do not differ a great deal from the pulmonary complications seen in a series of patients with rheumatoid arthritis by Aronoff, Bywaters, and Fearnley (1955).

TABLE XV

CLINICAL DIAGNOSES PERTAINING TO THE LUNGS IN 212 PATIENTS WITH ANKYLOSING SPONDYLITIS. COMPARED WITH THE 253 CASES OF RHEUMATOID ARTHRITIS ALSO FROM HAMMERSMITH HOSPITAL (Aronoff and others 1955)

\begin{tabular}{|c|c|c|c|c|}
\hline \multirow{2}{*}{\multicolumn{2}{|c|}{$\begin{array}{l}\text { Clinical Diagnosis } \\
\text { of Lung Disease }\end{array}$}} & & \multicolumn{2}{|c|}{ Series } \\
\hline & & : & $\begin{array}{l}\text { Ankylosing } \\
\text { Spondylitis }\end{array}$ & $\begin{array}{c}\text { Rheumatoid } \\
\text { Arthritis }\end{array}$ \\
\hline $\begin{array}{l}\text { No apparent disease } \\
\text { Bronchitis alone } \\
\text { Bronchitis and asthma } \\
\text { Bronchitis and emphysema } \\
\text { Emphysema alone .. } \\
\text { Bronchiectasis } \\
\text { Pulmonary tuberculosis } \\
\text { Pulmonary fibrosis . . } \\
\text { Bronchial carcinoma } \\
\text { Spontaneous pneumothora } \\
\text { Cyst of mediastinum } \\
\text { Other conditions . . }\end{array}$ & $\begin{array}{l}\cdots \\
\cdots \\
\cdots \\
\cdots \\
\cdots \\
\cdots \\
\cdots \\
\cdots\end{array}$ & $\begin{array}{l}\cdots \\
\cdots \\
\cdots \\
\cdots \\
\cdots \\
\cdots \\
\cdots \\
\cdots \\
\cdots \\
\cdots \\
\cdots\end{array}$ & $\begin{array}{r}190 \\
9 \\
4 \\
2 \\
0 \\
3 \\
10 \\
0 \\
2 \\
1 \\
1 \\
0\end{array}$ & $\begin{array}{r}180 \\
26 \\
3 \\
12 \\
8 \\
6 \\
7 \\
5 \\
2 \\
0 \\
0 \\
15\end{array}$ \\
\hline Total Cases .. & $\cdots$ & $\cdots$ & 212 & 253 \\
\hline
\end{tabular}

105 of the present patients had one or more chest $x$-ray examinations, and here again the results are similar to the findings of Aronoff and others (1955) in 130 patients with rheumatoid arthritis and a 
control group of non-rheumatoid patients (Table $\mathrm{XVI})$.

$$
\text { TABLE XVI }
$$

RADIOLOGICAL LUNG CHANGES IN PRESENT SERIES OF 212 SPONDYLITICS COMPARED WITH FINDINGS OF ARONOFF AND OTHERS (1955) IN PATIENTS WITH RHEUMATOID ARTHRITIS AND NON-RHEUMATOID CONTROLS

\begin{tabular}{|c|c|c|c|c|}
\hline \multirow{2}{*}{\multicolumn{2}{|c|}{$\begin{array}{l}\text { Radiological } \\
\text { Lung Changes }\end{array}$}} & \multicolumn{3}{|c|}{ Series } \\
\hline & & $\begin{array}{l}\text { Ankylosing } \\
\text { Spondylitis }\end{array}$ & $\begin{array}{c}\text { Rheumatoid } \\
\text { Arthritis }\end{array}$ & Controls \\
\hline $\begin{array}{l}\text { No lesion .. } \\
\text { Bronchitis and pneumoni } \\
\text { Emphysema } \\
\text { Bronchiectasis . . } \\
\text { Pulmonary tuberculosis } \\
\text { Pulmonary fibrosis } \\
\text { Bronchial carcinoma } \\
\text { Cyst of mediastinum } \\
\text { Other conditions... }\end{array}$ & $\begin{array}{l}\cdots \\
\cdots \\
\cdots \\
\cdots \\
\cdots \\
\cdots\end{array}$ & $\begin{array}{r}83 \\
5 \\
2 \\
2 \\
10 \\
1 \\
2 \\
1 \\
0\end{array}$ & $\begin{array}{r}68 \\
20 \\
13 \\
4 \\
14 \\
6 \\
2 \\
0 \\
21\end{array}$ & $\begin{array}{r}76 \\
18 \\
4 \\
2 \\
22 \\
0 \\
8 \\
0 \\
12\end{array}$ \\
\hline Cases $X$-Rayed & $\cdots$ & 105 & 130 & 130 \\
\hline Cases not $X$-Rayed & $\cdots$ & 117 & 123 & 0 \\
\hline Total Cases & $\ldots$ & 212 & 253 & 130 \\
\hline
\end{tabular}

This study does not confirm the suggestion that patients with ankylosing spondylitis, because of their limited respiratory excursion, are usually more susceptible to respiratory infections (Hamilton, 1949). However, the spondylitic may run a slight risk because quiescent pulmonary tuberculosis may be exacerbated by radiotherapy. This sequence was seen in two of the present patients with ultimately fatal results. In both cases $x$ rays before treatment showed no active disease but extensive pulmonary tuberculosis was found at 5 and 15 months after treatment.

(3) Haematological Complications.-Although most patients had a blood count when attending for their follow-up visit, only twelve showed haematological disorders. Eight had a hypochromic or normochromic anaemia, and three megaloblastic anaemia. Mild anaemia is considered to be frequent in ankylosing spondylitis, but was not observed here, possibly because most of the patients were observed at a late stage. One patient died from Hodgkin's disease. Another patient (Case 5) developed leukaemia six years after his first course of radiotherapy. As Court Brown and Abbatt (1955) have shown, there is an increased risk of leukaemia following spinal radiation for ankylosing spondylitis, particularly after multiple courses of radiotherapy.

Case 5, a male chauffeur aged 43 years in 1955, began to experience sacro-iliac pain in 1940 , shortly after entering military service. This was treated symptomatically for 2 years until an attack of dyspepsia precipitated his admission to hospital and a "bamboo spine" was noticed during the course of a barium meal. Following discharge from the forces he continued to have backache and stiffness until 1949 when he was treated by radiotherapy $(1,000 \mathrm{r}$ to each of four spinal fields). This gave partial relief, but a further course $(1,000 \mathrm{r}$ to each of five spinal fields) was more effective. The patient did light $\stackrel{\vec{S}}{\rightarrow}$ work without discomfort until 1955 when he was admitted to hospital for investigation of anaemia. This was found to be due to myeloblastic leukaemia and he died shortly afterwards.

(4) Gastro-intestinal Complications.-Since most of the drugs used in the treatment of ankylosing spondylitis may cause dyspepsia, its occurrence in $\overrightarrow{0}$ 24 patients during the course of their spondylitis is not surprising. This association has been emphasized by Morrison (1955). In three patients their dyspepsia was due to neoplasm (stomach and pancreas), in thirteen to peptic ulcers demonstrated on $x$ ray or post mortem, and in one to oesophagitis. Four patients had negative barium meal examinations and three were not $x$ rayed. Three of these patients first noticed dyspepsia while taking phenylbutazone, and when the drug was withdrawn the dyspepsia subsided

According to Doll and Jones (1951), the incidence of peptic ulcer in the adult male population of $\vec{E}$ London is between 5 and 10 per cent. The figurg 9 of thirteen male patients in the present series is ne greater than this normal incidence. Four patien. suffered from ulcerative colitis and one from Crohn's disease. This compares with an incidence of three cases of ulcerative colitis in a series of 117 spondylitics reported by Romanus (1953). Though the frequency of ulcerative colitis in the general population is uncertain, Kantor (1929) found only nine cases in 1,000 patients with gastro-enterological complaints, and Spriggs (1934) mentions five cases in 1,000 hospital admissions. It seems therefore that there may be an association between ulcerative colitis and ankylosing spondylitis.

(5) Spinal Fractures and Subluxations.--These rarely complicate ankylosing spondylitis; however, Sharp and Purser (1957) have recently drawn attention to an easily overlooked complication, $v i-$. $\frac{7}{0}$ spontaneous atlanto-axial subluxation. They suggest that this should be considered in any spondylitic N with pain or deformity in the cervical region, whether or not neurological signs are present.

In the present cases there were no patients with cervical spine fractures, but one patient complaining of neck pain was found to have atlanto-axial subluxation (Fig. 12, opposite).

Two further patients had fractures of the lumbar? spine, one following an injury and the other (Case 6) spontaneously in a porotic spine (Fig. 13, opposite). 
Case 6, a housewife aged 37 years in 1952, was treated in hospital for 7 months at the age of 13 for an attack of polyarthritis diagnosed as rheumatic fever. Only 4 months after her recovery she began to suffer from sacro-iliac pain and at the age of 17 radiological changes were demonstrated in the sacro-iliac joints. During the next 20 years she received three courses of deep $x$-ray therapy with considerable relief of pain but without preventing ankylosis of the spine. At the age of 30 she became pregnant and the disease remitted, but 4 months after a normal delivery she suffered an exacerbation with transient peripheral arthritis. After the age of 36 she developed progressive kyphosis with angulation at the upper lumbar region, and the $x$ rays showed extremely porotic vertebral bodies with a crush fracture of the second lumbar vertebra. This was confirmed after death one year later which was due to an exacerbation of bronchiectasis or cor pulmonale. Neither clinically nor at post mortem was there any evidence of rheumatic heart disease. The sister of this patient is also included in this series.

(6) Psoriasis.--Four patients suffered from extensive psoriasis of the body and limbs, beginning before or at the same time as the spondylitis. Three of them showed peripheral joint lesions, especially of

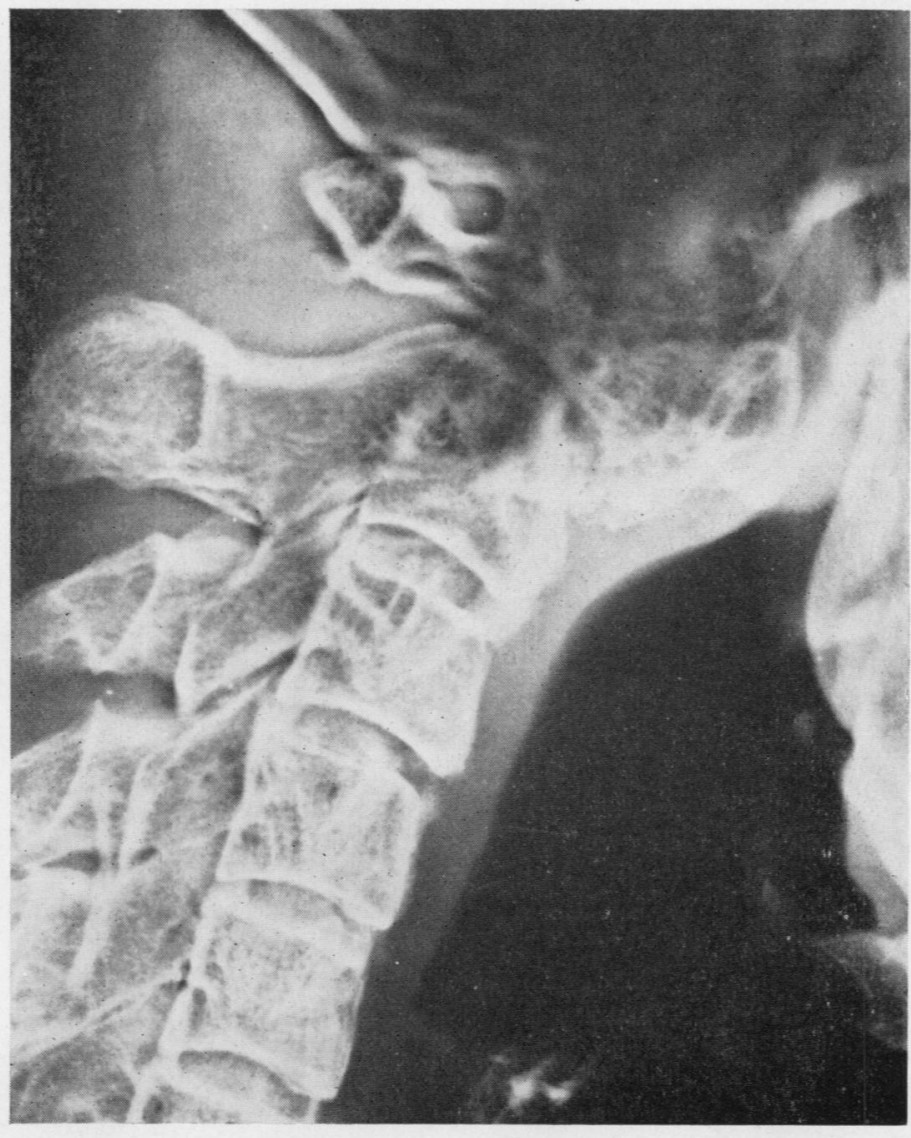

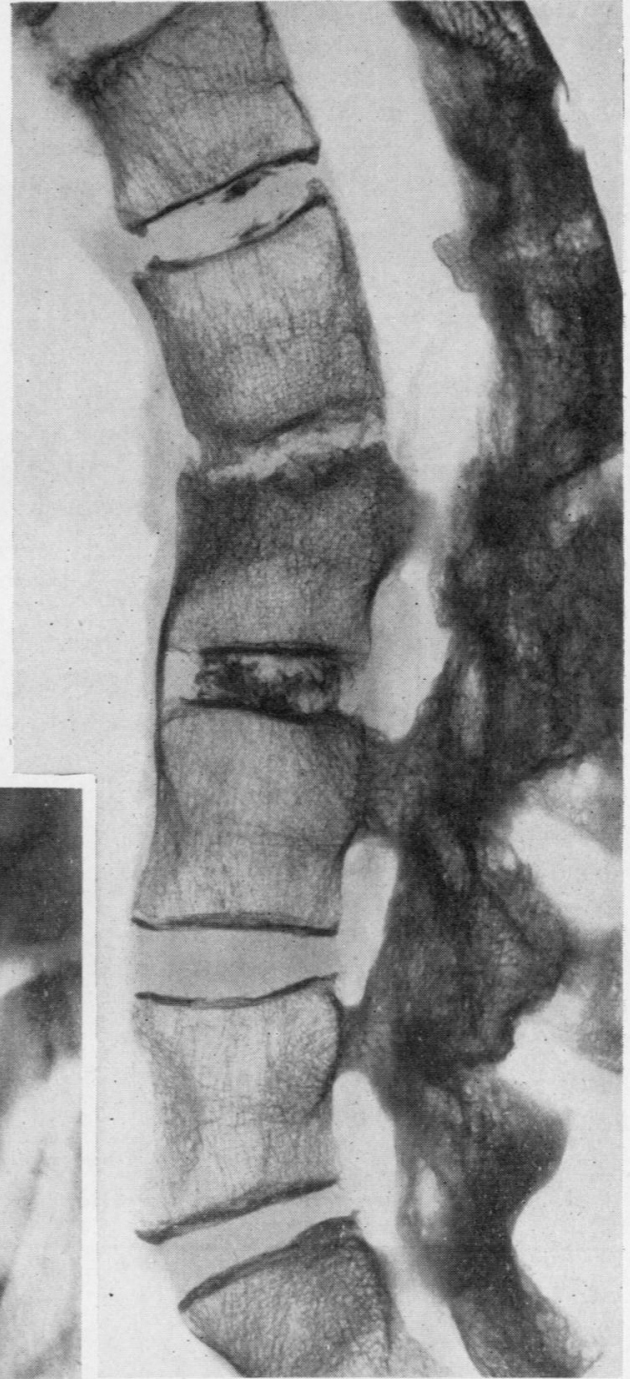

Fig. 13.-Crush fracture of a porotic lumbar vertebra in a patient with long-standing ankylosing spondylitis. 
the hands and feet, progressing in two cases to arthritis mutilans and ankylosis of the metatarsophalangeal and interphalangeal joints. The terminal interphalangeal joints were involved in two patients. The spondylitis was otherwise quite typical and three patients treated with radiotherapy responded well.

Two of the above patients suffered from ulcerative colitis and psoriasis as well as ankylosing spondylitis with peripheral joint involvement.

(7) Urethritis.-Eight patients gave a history of urethritis before and one shortly after the onset of the spondylitis. No case presented the full picture of Reiter's disease, but in four of these patients the urethritis and peripheral arthritis coincided. Five patients suffered from uveitis. There were no clinical, serological, or radiological features which would differentiate these cases from the remainder of the series, but of the eight patients treated with radiotherapy only four benefited.

(8) Cardiovascular Complications.-Cardiovascular lesions were found in sixteen patients (Table XVII). Only three showed chronic rheumatic valvular lesions, though a history of past "rheumatic fever" was fairly common (25 patients). However, eleven of these patients described a chronic arthritis, often with permanent sequelae and followed by intermittent backache. It seems that any arthritis in a young person is likely to be called rheumatic fever and this applies particularly to ankylosing spondylitis with a peripheral joint onset.

TARLE XVII

CARDIOVASCULAR COMPLICATIONS IN 222 PATIENTS WITH ANKYLOSING SPONDYLITIS (DETECTED CLINICALLY)

\begin{tabular}{cccccc}
\hline Ischaemic heart disease & $\ldots$ & $\ldots$ & $\ldots$ & $\ldots$ & 4 \\
Pericarditis. & $\ldots$ & $\ldots$ & $\ldots$ & $2^{*}$ \\
Rheumatic valvular disease & $\ldots$ & $\ldots$ & $\ldots$ & 2 \\
"Rheumatoid aortitis" $\ldots$ & $\ldots$ & $\ldots$ & $\ldots$ & 2 \\
Hypertensive heart failure & $\ldots$ & $\ldots$ & $\ldots$ & 1 \\
Cor pulmonale . & $\ldots$ & $\ldots$ & $\ldots$ & $\ldots$ & 1 \\
Intermittent claudication .. & $\ldots$ & $\ldots$ & $\ldots$ & 13 \\
\hline Total . & $\ldots$ & $\ldots$ & $\ldots$ & $\ldots$ & 13 \\
\hline
\end{tabular}

* Further lesions, discovered only at post-mortem examination included adherent pericardium (two patients) and a sclerosed mitral valve (one patient).

Two patients developed lone aortic incompetence while under observation at intervals of 7 and 12 years after the onset of their spondylitis. and these are to be separately reported. In both cases there was peripheral joint involvement and cardiograms showed prolongation of the PR interval, to 0.25 and $0.24 \mathrm{sec}$. respectively. Neither showed subcutaneous nodules. Wassermann and Treponema pallidum immobilization tests were negative. It seems probable that these two patients suffer from what Bauer, Clark, and Kulka (1951) have called "rheumatoid aortitis".

Two patients developed transient pericarditis during the course of their spondylitis and two further patients showed extensive pericardial adhesions post mortem.

(9) Pregnancy.-This does not seem to have the same uniformly favourable influence on ankylosing spondylitis as on rheumatoid arthritis, for only three out of seven patients noted improvement during pregnancy. In four the spondylitic symptoms persisted or were aggravated during the course of eight pregnancies. One further patient dated the onset of her spondylitis from the post-puerperal period.

\section{Discussion}

It may be questioned whether comparisons between different disease duration groups can be used to deduce the course of a disease. For example, patients first attending hospital when symptoms have been present for more than 5.years (rather more than half of the present cases) may represent only those in whom the disease has progressed and may not include those who have become quiescent during this period. This would give an unfavouro able bias to interpretations of the course of the disease. Furthermore, with such comparisons it is difficult to assess the effect of increasing age, which? quite apart from the disease is likely to affect a patient's functional capacity and employment. Therefore, the present findings were carefully analysed in an attempt to evaluate these two complications.

Table II shows that the type of case referred to hospital during the period 1940-1955 did not vary except in the one respect that the patients seen during 1951-1955 showed a significantly better initial functional status $(p=<0.05)$ than did the earlier cases. If the course of ankylosing spondylitis is truly progressive, it would be expected that those patients followed for longer periods will have deteriorated more than patients recently seen, and this seems to be so.

Table XVIII (opposite) shows the mean functional status, the mean employment index, and the mean deformity index (graded as in Figs 8, 9. and 10) derived from the recent follow-up data, correlated with the time of first attendance. Each index falls (i.e. deterioration occurs) with increasing length of follow-up, and calculations based on the actual numbers of patients show the differences to be significant $(p-<0.05)$ in each instance. A similar change is seen in chest expansion.

Furthermore, each follow-up group has been 
TABLE XVIII

MEAN STATUS WITH REGARD TO FUNCTIONAL ABILITY, EMPLOYMENT, AND DEFORMITY AT FOLLOW-UP, IN 211* SPONDYLITIC PATIENTS GROUPED ACCORDING TO TIME WHEN FIRST SEEN AND DURATION OF SYMPTOMS WHEN FIRST SEEN. GRADES OF FUNCTION, EMPLOYMENT, AND DEFORMITY ARE THOSE DEFINED IN FIGURES 8, 9, AND 10. PATIENTS NOW DEAD WERE GRADED ACCORDING TO THEIR STATE BEFORE THE TERMINAL ILLNESS

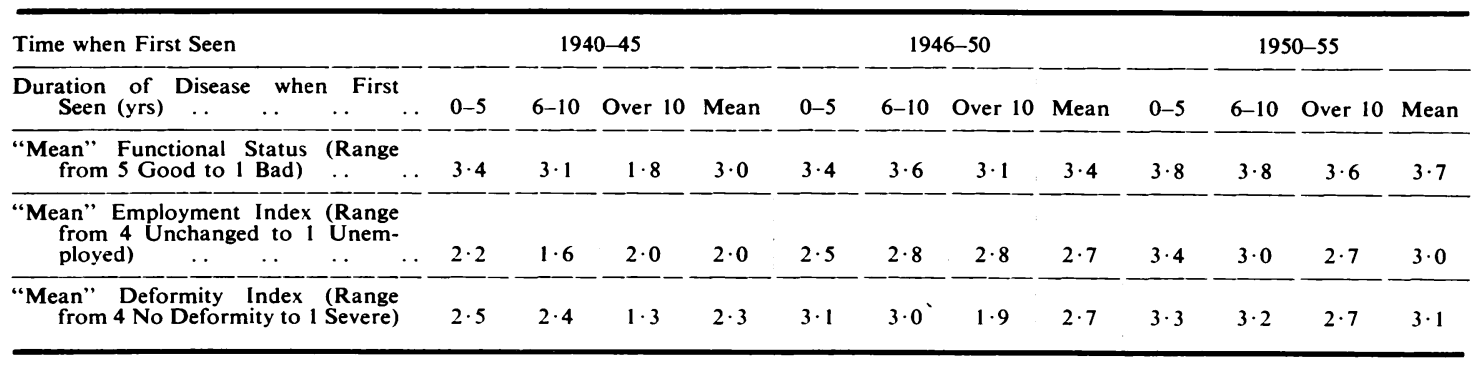

* One further patient was omitted because duration of illness was not known.

subdivided according to the duration of symptoms when first seen. Here again there is a constant deterioration when, for instance, the patients with symptoms of short duration and first seen during 1951-1955 are compared with the corresponding group first seen during 1940-1945. Such a comparison suggests that the deterioration is genuine and not due to selection bias. If the Table is compiled for those living at the time of follow-up only, similar trends are seen.

However, this deterioration might simply be due to advancing age, since the average age of the $1-$ to 5 -year duration group shown in Figs 8, 9, and 10 was 32.3 years compared with 51.6 years for the group which had had symptoms for more than 20 years.

In order to reduce this age factor, those patients aged 31-50 years in January, 1956, were analysed separately. Here again there was a slight deterioration in functional status and employment status with increasing duration of symptoms but the differences were not statistically significant. The figures for deformity, however, showed a more striking and statistically significant increase $(p=<0.01)$ with increasing duration of symptoms.

If the foregoing data is now used to indicate the course of ankylosing spondylitis the following picture emerges.

In most instances the onset is insidious with initial symptoms in the lower spine or peripheral joints, the latter being more common in adolescents. At this stage there has always been evidence of sacro-iliac involvement in our cases, though a few are recorded in the literature with such changes only subsequently.
The disease then progresses by a series of exacerbations and remissions. Although it is usually considered that the disease may become completely arrested at any stage, the present study suggests that this is exceptional. In many cases the spine gradually becomes more extensively involved, deformity more marked, and chest expansion more limited, over periods up to 30 years. In many patients with apparently quiescent disease, attacks of iritis continue. Almost one-half of the total group show a raised erythrocyte sedimentation rate at follow-up, which further suggests that the disease is not really inactive.

On the other hand, root and peripheral joint involvement tends to occur in the early years of the disease and, although established peripheral joint lesions usually progress, it is uncommon for new peripheral joint lesions to appear after the first 10 years of the illness. This strange divergence of behaviour in the spinal and peripheral joints is difficult to explain. While the basic inflammatory mechanism is probably the same for both sets of joints, it may be that the progress and type of lesion is influenced by the stresses and strains sustained. Thus the weight-bearing joints tend to be affected far more frequently than the non-weightbearing joints. This would explain the progression of the disease in the spine, which continues to transmit weight even after the spondylitic becomes chairbound. On the other hand, as the disease advances and the patient's activities become more restricted, less burden is imposed upon the extraspinal joints.

Throughout the course of the disease there is a very slow decline in the patient's functional capacity, but in the absence of a control group of normal 
subjects it is difficult to be certain whether this is due to the disease or to advancing age. After a few years, patients can no longer indulge in heavy physical labour or recreation and after 10 years of illness, most spondylitics are reduced to sedentary or light occupations. Nevertheless, most patients continue to be fully employed and self-supporting for decades after the onset of symptoms and the disease only rarely seems to shorten life.

The main factor influencing the prognosis is the presence or absence of extraspinal joint involvement, for this is considerably more disabling than spinal arthritis, especially when it affects the weightbearing joints. If the disease begins after the age of 30 years, or if symptoms have been present for 10 years without evidence of extraspinal joint involvement, the patient will probably escape with a rigid spine but without extraspinal joint lesions. If radiotherapy is to be used, then in our experience it will give better symptomatic results if used early, before there is evidence of extensive spinal involvement. In view of the potential risk of leukaemia (Court Brown and Abbatt, 1955), only those spinal areas which are causing symptoms should be treated, thus exposing a minimum of haemopoietic tissue to the irradiation. Multiple courses of radiotherapy should be eschewed.

We have viewed this group as a single entity, since we have not found consistent differences between such subgroups as Sharp (1957) has differentiated, on the basis of association with rheumatic fever or its consequences, psoriasis, rheumatoid arthritis, or urethritis (Reiter's disease), but our case material is less than half that collected by Sharp:

(1) Rheumatic Heart Disease.-If we separate off the two cases with late developing aortic valvulitis, as described by Bauer and others (1951), the incidence of rheumatic valvulitis (i.e. with mitral involvement), is so low in our series $(1.4$ per cent.) that it can safely be ascribed to coincidence. Although 25 patients gave a history of a previous illness diagnosed as rheumatic fever, eleven of them described it as a chronic peripheral arthritis, often with permanent sequelae and followed by intermittent backache. It was probably the beginnings of ankylosing spondylitis. The peripheral arthritis in such cases did not resemble that described by Bywaters (1950) as "Jaccoud's syndrome". Further, while there is no inherent unlikelihood in a Jaccoud-type fibrosis affecting the spine as well as the peripheral joints, as postulated by Thomas (1955), we have not been able to recognize in our cases the radiological peculiarities of the central joints described by Thomas (1955) and by Sharp (from the same material, 1957), i.e. "small erosions of the sacro-iliac joints with spotty areas of sclerosis, irregularity and fusion of the apophyseal joints, narrowed intervertebral disk spaces with increased height of the verteral bodies". Nor have we seen the normal chest expansion and tendon nodules described by Sharp (1957) in such cases. Indeed, Case 7, one of our otherwise typical cases of ankylosing spondylitis, without peripheral joint lesions or heart lesions and without evidence of previous rheumatic fever, has a peculiar cervical spine (Fig. 14) very closely resembling one claimed to represent a Jaccoud's syndrome of the spine (Thomas, 1955; Case 27, Fig. 3). It seems possible that such tall, narrow vertebrae may be due to interference with growth at the ring epiphyses before they unite and may thus date the lesion (see similar growth defects in Still's disease; Ansell and Bywaters, 1956).

Case 7, a male ex-shop assistant aged 49 years in 1956, had noticed aching pains in the buttocks and thighs when aged 19 years, which later spread to the remainder of the spine. At the age of 33 years the whole spine was rigid and movement at the hip joints was limited. He received various treatments, including radiotherapy to the whole spine and both hip joints, with considerable relief of pain. There was no history of rheumatic fever or of peripheral joint involvement and the heart was clinically normal. When last seen in 1956 a sedimentation rate was $3 \mathrm{~mm}$. $/ \mathrm{hr}$ (Westergren), and a sheep cell agglutination test was negative. An $x$ ray of this man's cervical spine is shown in Fig. 14.

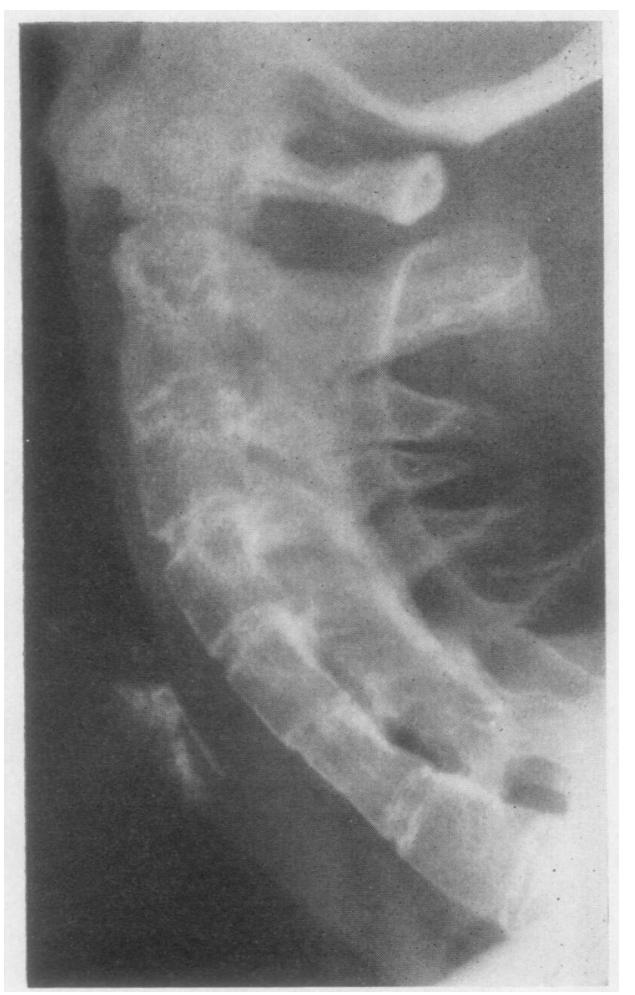

Fig. 14.-Cervical spine of a patient with ankylosing spondylitis beginning at the age of 19 years. Note abnormal shape of vertebral bodies, possibly due to abnormal growth at ring epiphyses. 
(2) "Psoriatic Spondylitis".-The association of psoriasis with ankylosing spondylitis, emphasized recently by Fletcher and Rose (1955), again did not appear to produce any easily recognizable subgroup. The incidence of psoriasis in our series was 1.8 per cent. (4 in 222) compared with 4 in 100 (Fletcher and Rose). While ankylosis of the small finger and toe joints occurred in two of these, we have also seen this occur in long-standing ankylosing spondylitis not associated with psoriasis. The terminal interphalangeal joints were affected in two of the patients with psoriasis but in none of the other patients.

(3) "Rheumatoid Spondylitis".--In Great Britain, ankylosing spondylitis is thought to be a separate entity from rheumatoid arthritis, distinguished by age and sex incidence, negative Rose test, frequent presence of uveitis, absence of nodules, and good response to radiotherapy. While it is recognized that the cervical spine is frequently involved in rheumatoid arthritis, involvement of the lower spine and sacro-iliac joints is seldom seen.

Spondylitis with sacro-iliac joint involvement due to rheumatoid arthritis as distinct from ankylosing spondylitis, was not recognized in this series, although, in one patient, pericarditis and multiple subcutaneous nodules of the rheumatoid type (but with a negative Rose test) coming on with peripheral joint involvement some 24 years after a typical ankylosing spondylitis, inclined us to postulate the presence of both diseases. While the morphology of peripheral joints in this case resembled that of rheumatoid arthritis, the same is true of otherwise typical ankylosing spondylitis with peripheral joint involvement. We were unable to distinguish a rheumatoid sacro-iliitis radiologically, as described by Sharp (1957).

(4) "Reiter's Spondylitis".- -The acquisition of a gleet as a sign of attaining manhood is no longer as popular and as widespread as it was in Boswell's time but, in a predominantly young male group, more than urethritis (or a history of it) and ankylosing spondylitis should be deemed necessary to make a "Reiter's spondylitis" (Sharp, 1957). While nine of our cases admitted to past urethritis when directly questioned, in only three did the arthritis develop soon after an attack of urethritis. Though five of these patients also developed uveitis, this occurred several years after the urethritis. No patient showed keratodermia and the spondylitis was in no way unusual. In only two patients were the feet and ankles affected.

The occurrence of ankylosing spondylitis following Reiter's disease is now well known, and Ford (1953) found four such cases among patients with "venereal arthritis" attending the London Hospital.

It is of interest that Romanus (1951) has tried to incriminate chronic urogenital infection in the aetiology of ankylosing spondylitis; this occurred in a majority of his series of 117 male Swedes, and Romanus has suggested that infection or toxic products reach the spine by way of the prevertebral veins but that arthritis only results if other factors are present, notably a familial diathesis.
Such a hypothesis does not explain the peripheral joint lesions.

The essential lesion in ankylosing spondylitis appears to be involvement of the apophyseal joints: it seems likely that bambooing is secondary and could result from immobilization of the spine together with local inflammatory disease due to any cause. Thus, bridging is seen locally with almost any focal inflammatory spinal lesion. While, therefore, it appears possible for ankylosing spondylitis to occur following colitic, psoriatic, "Reiter's", rheumatoid, or "Jaccoud's" disease of the apophyseal joints, just as it may follow local brucellar involvement, we have not felt in this comparatively limited survey that we could distinguish any such subtypes, either on radiological or on clinical grounds. The general pattern of disease as shown in this series is remarkably uniform.

\section{Summary}

212 out of 222 patients suffering from ankylosing spondylitis and treated at the Hammersmith Hospital between January, 1940, and December, 1955, have been traced and studied. Their present physical and functional state suggests that ankylosing spondylitis is usually a slowly progressive condition without permanent complete remission. Spinal involvement, deformity, and limitation of chest expansion all show slow but progressive deterioration with increasing duration of the disease. Iritis continues to recur and a raised erythrocyte sedimentation rate is frequent even in long-standing and apparently inactive cases. However, in the later stages of the illness, the tempo of the disease process is retarded, and it is unusual to find new peripheral joint lesions or first evidence of iritis at this stage.

Despite illness of more than 20 years' duration, a patient's functional capacity may be remarkably little impaired when one makes allowance for age; 63 per cent. of the living patients were employed in full-time light occupations, whereas only 18 per cent. were severely deformed.

200 of these patients had received radiotherapy on one or more occasions; it did not seem to arrest disease activity more than temporarily. The proportion of patients with a symptomatic relapse after radiotherapy rose from $67 \cdot 4$ per cent. at one year after treatment to 90 per cent. after follow-up periods of more than 10 years.

We wish to thank Drs. C. A. P. Wood and R. Morrison for allowing us to study patients under their care, and Dr. E. Lewis-Faning for helpful and valued criticism on statistical aspects.

\section{REFERENCES}

Ansell, B. M., and Bywaters, E. G. L. (1956). Ann. rheum. Dis., 15, 295 .

Aronoff. A., Bywaters, E. G. L., and Fearnley, G. R. (1955). Brit. med. J., 2,228

Bauer, W., Clark, W.'S., and Kulka, J. P. (1951). Ann. rheum. Dis., Blumberg, B., and Ragan, C. (1956). Medicine (Baltimore), 35, 1. 
Borak, J. (1946). Radiology, 47, 128

Bywaters, E. G. L. (1950). Brit. Heart J., 12, 101

Bywaters, E. (1954). Ann. rheum. Dis., 13, 42.

Court Brown, W. M., and Abbatt. J. D. (1955). Lancet, 1, 1283.

Desmarais, M. H. L. (1953). Ann. rheum. Dis., 12. 25.

Doll, R... and Jones, F. A. (1951). Spec. Rep. Ser.. Med. Res. Coun. No. 276 . H.M.S.O., London

Fletcher. E. and Rose, F. C. (1955). Lancet, 1, 695.

Ford, D. K. (1953). Ann. rheum. Dis., 12. 177.

Ford, D. K. (1953). Ann. rheum. Dis.,
Forestier, J. (1939). Radiology, 33, 389.

Forestier, J. (1939). Radiology, 33, 389.
Hamilton. K. A. (1949). Ann. intern. Med., 31, 216.

Hart, F. Dudley. Bogdanovitch, A.. and Nichol, W. D. (1950). Ann. rheum. Dis., 9, 116.

and Maclagan, N. F.(1955). Ibid., 14, 77.

- Robinson, K. C.. Allchin, F. M.. and Maclagan, N. F. (1949). Quart. J. Med.. N.S. 18, 217

Kantor, J. L. (1929). Bull. N.Y. Acad. Med., 5. 757.

Morrison, R. J. G. (1955). Proc. rov. Soc. Med. 48, 204

Morrison, R. J. G. (1955). Proc. roy. Soc. Med. 48, 204.
Oppenheimer, A. (1943). Amer. J. Roentgenol., 49, 49.

Polley, H. F., and Slocumb, C. H. (1947). Ann. intern. Med., 26, 240

Romanus, R. (1953). Acta med. scand., Suppl. 280.

- and Ydén, S. (1955). "Pelvo-spondylitis Ossificans": Rheumatoid or Ankylosing Spondylitis, trans. J. Whitehouse. Munksgaard. Copenhagen

Sharp. J. (1957). Brit. med.J.. 1. 975.

Sharp. J. (1957). Brit. med. J.. 1. 975. 619 and Easson, E. C. (1954). Ibid.. 1. 619

Smythe, H. A. (1956). Ann. rheum. Dis., 15, 271.

Sorsby, A.. and Gormaz, A. (1946). Brit. med. J., 1. 597

Spriggs, E. I. (1934). Ouart. J. Med., N.S. 3. 549

Thomas. A. E. (1955). Ann. rheum. Dis., 14, 259.

Caractères cliniques et évolution de la spondylarthrite ankylosante, d'après l'observation de 222 cas vus à l'hôpital

RÉSUMÉ

On a retrouvé et re-examiné 212 sur 222 malades atteints de spondylarthrite ankylosante et traités à l'hôpital Hammersmith (Londres) entre le mois de janvier, 1940 et le mois de décembre, 1955. Leur état physique et fonctionnel présent suggère que la spondylarthrite ankylosante est habituellement une maladie lentement évolutive, sans remission complète et permanente. L'implication de la colonne vertébrale, la déformation et la limitation de l'expansion de la poitrine accusent une détérioration lente mais constante avec le temps. L'irite revient toujours et la vitesse de sédimentation globulaire élevée est fréquente même dans les cas anciens et apparemment inactifs. Cependant, à des périodes plus avancées de la maladie, le tempo du processus morbide est ralenti et il est alors très rare de trouver une lésion dans une articulation périphérique nouvelle ou le commencement d'une irite.
Même lorsque la maladie dure 20 ans ou plus, la capacité fonctionnelle du malade peut se trouver remarquablement peu altérée, pourvu qu'on tienne compte de son âge; $63 \%$ des malades survivants avaient un emploi léger mais à pleines journées et $18 \%$ seulement avaient des difformités sévères.

Deux cents de ces malades ont reçu de la radiothérapie une fois ou plus; cela ne semblait arrêter l'activité morbide que temporairement. La proportion des malades ayant une rechute symptomatique après la radiothérapie monta de $67,4 \%$ au bout d'un an à $90 \%$ au bout de 10 ans.

\section{Rasgos clínicos y evolución de la espondilartritis anquilosante, según la observación de 222 casos vistos en hospital \\ Sumario}

Se revistaron 212 de los 222 enfermos con espondilartritis anquilosante, tratados en el hospital de Hammersmith (Londres) entre enero de 1940 y diciembre de 1955. $\mathrm{Su}$ estado físico y funcional presente sugiere que la espondilartritis anquilosante es generalmente una enfermedad lentemente evolutiva, sin remisión completa y permanente. La implicación de la columna vertebral. la deformación y la limitación de la expansión del pecho acusan un deterioro lento pero constante con el tiempo. La iritis vuelve a recurrir y la velocidad de sedimentación eritrocitaria es frecuentemente alta hasta en los casos y aparentemente poco activos. Sin embargo, en los períodos más adelantados de la enfermedad, el proceso mórbido se ve retardado y entonces lesiones de una articulación periférica nueva o el comienzo du una iritis son rarísimas.

La enfermedad puede durar 20 años o más, con notablemente poca alteración de la capacidad funcionalo provisto que se tome en cuenta la edad del enfermo? el $63 \%$ de los enfermos sobrevivientes tenían una ocupación leve pero constante y tan sólo un $18 \%$ tenían deformaciones severas.

Dos cientos de estos enfermos recibieron radioterapia una vez o más; esto no pareció detener la acrividad mórbida más que temporariamente. La proporción de los enfermos sufriendo una recaída sintomática después de la radioterapia subió de un $67.4 \%$ al cabo de un año a un $90 \%$ al cabo de 10 años. 